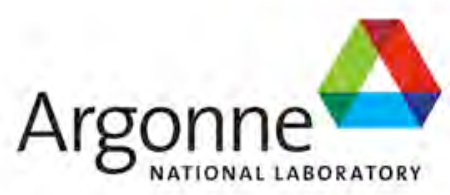

ANL/EXT-11/46

\title{
Creep Rupture Testing of Alloy 617 and A508/533 Base Metals and Weldments
}

K. Natesan, Meimei Li, W. K. Soppet, and D. L. Rink Nuclear Engineering Division

September 2011

\section{Argonne National Laboratory \\ Argonne, IL 60439}

Sponsored by the Idaho National Laboratory

for the U.S. Department of Energy

Office of Nuclear Energy, Science, and Technology

Argonne is operated by UChicago Argonne, LLC under DOE Contract DE-AC02-06CH11357. 


\begin{abstract}
About Argonne National Laboratory
Argonne is a U.S. Department of Energy laboratory managed by UChicago Argonne, LLC under contract DE-AC02-06CH11357. The Laboratory's main facility is outside Chicago, at 9700 South Cass Avenue, Argonne, Illinois 60439. For information about Argonne, see www.anl.gov.
\end{abstract}

\title{
Availability of This Report
}

This report is available, at no cost, at http://www.osti.gov/bridge. It is also available on paper to the U.S. Department of Energy and its contractors, for a processing fee, from:

U.S. Department of Energy

Office of Scientific and Technical Information

P.O. Box 62

Oak Ridge, TN 37831-0062

phone (865) 576-8401

fax (865) 576-5728

reports@adonis.osti.gov

\begin{abstract}
Disclaimer
This report was prepared as an account of work sponsored by an agency of the United States Government. Neither the United States Government nor any agency thereof, nor UChicago Argonne, LLC, nor any of their employees or officers, makes any warranty, express or implied, or assumes any legal liability or responsibility for the accuracy, completeness, or usefulness of any information, apparatus, product, or process disclosed, or represents that its use would not infringe privately owned rights. Reference herein to any specific commercial product, process, or service by trade name, trademark, manufacturer, or otherwise, does not necessarily constitute or imply its endorsement, recommendation, or favoring by the United States Government or any agency thereof. The views and opinions of document authors expressed herein do not necessarily state or reflect those of the United States Government or any agency thereof, Argonne National Laboratory, or UChicago Argonne, LLC.
\end{abstract}




\section{Executive Summary}

The NGNP, which is an advanced HTGR concept with emphasis on both electricity and hydrogen production, involves helium as the coolant and a closed-cycle gas turbine for power generation with a core outlet/gas turbine inlet temperature of $750-1000^{\circ} \mathrm{C}$. Alloy 617 is a prime candidate for VHTR structural components such as reactor internals, piping, and heat exchangers in view of its resistance to oxidation and elevated temperature strength. However, lack of adequate data on the performance of the alloy in welded condition prompted to initiate a creep test program at Argonne National Laboratory. In addition, Testing has been initiated to evaluate the creep rupture properties of the pressure vessel steel A508/533 in air and in helium environments. The program, which began in December 2009, was certified for quality assurance NQA-1 requirements during January and February 2010. Specimens were designed and fabricated during March and the tests were initiated in April 2010.

During the past year, several creep tests were conducted in air on Alloy 617 base metal and weldment specimens at temperatures of 750,850 , and $950^{\circ} \mathrm{C}$. Idaho National Laboratory, using gas tungsten arc welding method with Alloy 617 weld wire, fabricated the weldment specimens. Eight tests were conducted on Alloy 617 base metal specimens and nine were on Alloy 617 weldments. The creep rupture times for the base alloy and weldment tests were up to $\sim 3900$ and $\sim 4500 \mathrm{~h}$, respectively. The results showed that the creep rupture lives of weld specimens are much longer than those for the base alloy, when tested under identical test conditions. The test results also showed that the creep strain at fracture is in the range of 7$18 \%$ for weldment samples and were much lower than those for the base alloy, under similar test conditions.

In general, the weldment specimens showed more of a flat or constant creep rate region than the base metal specimens. The base alloy and the weldment exhibited tertiary creep after $50-60 \%$ of the rupture life, irrespective of test temperature in the range of $750-950^{\circ} \mathrm{C}$. The results showed that the stress dependence of the creep rate followed a power law for both base alloy and weldments. The data also showed that the stress exponent for creep is the same and one can infer that the same mechanism is operative in both base metal and weldments in the temperature range of the current study.

SEM fractography analysis indicated that both base metal and weldment showed combined fracture modes consisting of dimple rupture and intergranular cracking. Intergranular cracking was more evident in the weldment specimens, which is consistent with the observation of lower creep ductility in the weldment than in the base metal. 


\section{Contents}

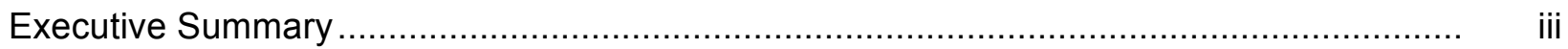

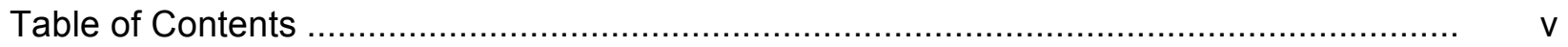

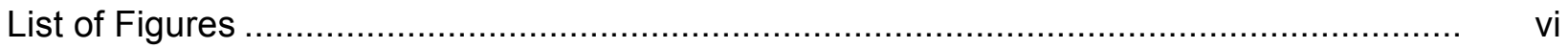

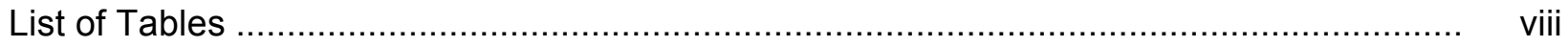

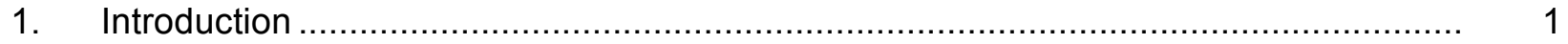

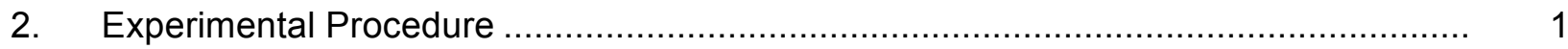

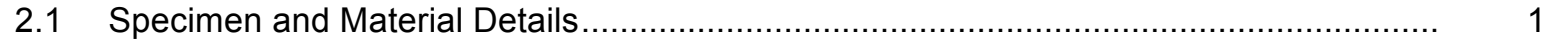

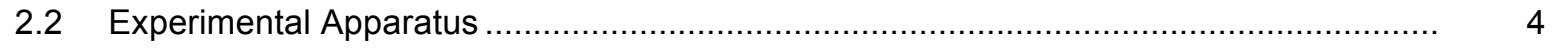

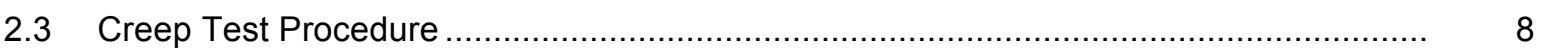

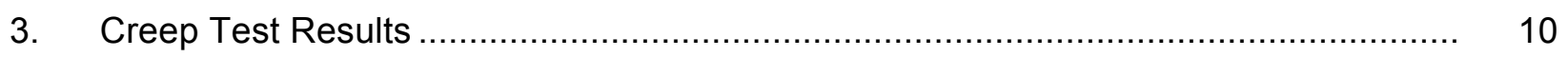

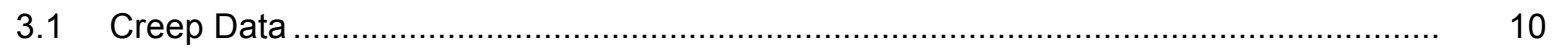

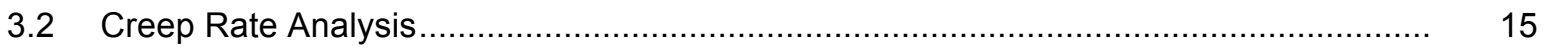

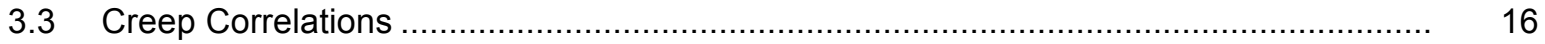

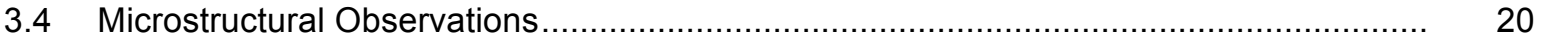

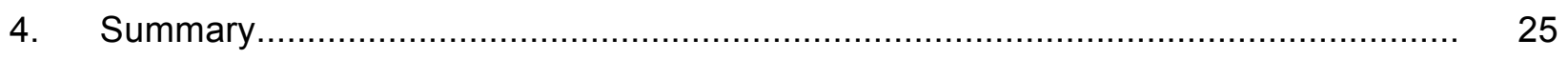

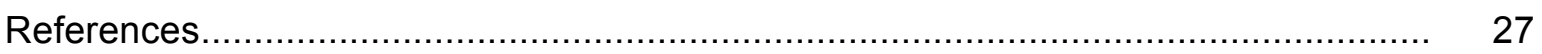




\section{List of Figures}

Figure 1. Creep specimen fabrication drawing ........................................................ 2

Figure 2. Creep weldment specimen fabrication drawing .......................................... 2

Figure 3. Creep specimen No. 210-1 weld region dimensions and a typical hardness profile along the axial direction of the welded gage section

Figure 4. Overall view of direct-load creep test facility for air and gas environments .......... 6

Figure 5. Overall view of lever-arm creep test facility for air and gas environments ............ 7

Figure $6 . \quad$ Schematic and detail views of creep specimen load train ............................... 8

Figure 7. A comparison of the creep behavior of base metal and weldment of Alloy 617,

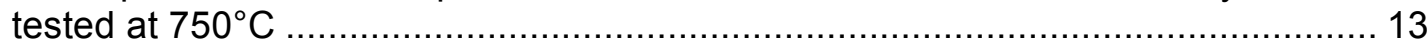

Figure 8. Creep behavior of weldment of Alloy 617 tested at $750^{\circ} \mathrm{C}$ and at two applied stress levels

Figure 9. A comparison of the creep behavior of base metal and weldment of Alloy 617 tested at $850^{\circ} \mathrm{C}, \sim 43 \mathrm{MPa}$

Figure 10. A comparison of the creep behavior of base metal and weldment of Alloy 617 tested at $850^{\circ} \mathrm{C}, \sim 54 \mathrm{MPa}$.

Figure 11. A comparison of the creep behavior of base metal and weldment of Alloy 617 tested at $850^{\circ} \mathrm{C}, \sim 61.3-63.1 \mathrm{MPa}$.

Figure 12. A comparison of the creep behavior of base metal and weldment of Alloy 617 tested at $950^{\circ} \mathrm{C}, \sim 28.5 \mathrm{MPa}$.

Figure 13. A comparison of the creep behavior of base metal and weldment of Alloy 617 tested at $950^{\circ} \mathrm{C}, 24.1 \mathrm{MPa}$. 15

Figure 14. A comparison of the creep behavior of base metal and weldment of Alloy 617 tested at $950^{\circ} \mathrm{C}, 18.5 \mathrm{MPa}$. 15

Figure 15. Plots of creep strain rate versus time calculated from the creep curves for some of the tests conducted at 750,850 , and $950^{\circ} \mathrm{C}$ on base metal and weldment of Alloy 617

Figure 16. Plot of applied stress versus rupture time for base metal and weldment of Alloy 617 tested at $750-950^{\circ} \mathrm{C}$.....

Figure 17. Plot of applied stress versus steady state creep rate for base metal and weldment of Alloy 617 tested at $750-950^{\circ} \mathrm{C}$

Figure 18. Plot of applied stress versus rupture strain for base metal and weldment of Alloy 617 tested at $750-950^{\circ} \mathrm{C}$

Figure 19. Plot of applied stress versus reduction in area for base metal and weldment of Alloy 617 tested at $750-950^{\circ} \mathrm{C}$

Figure 20. Plot of steady state creep rate versus applied stress for base metal and weldment of Alloy 617 tested at $750-950^{\circ} \mathrm{C}$

Figure 21. Plot of applied stress versus Larson Miller parameter for base metal and weldment of Alloy 617 tested at $750-950^{\circ} \mathrm{C}$ 
Figure 22. SEM micrographs of the fracture surfaces for Alloy 617 base metal tested at the stress level of $137.8 \mathrm{MPa}$ at $750^{\circ} \mathrm{C}$ in air

Figure 23. SEM micrographs of the fracture surfaces for Alloy 617 base metal tested at the stress level of $63.1 \mathrm{MPa}$ at $850^{\circ} \mathrm{C}$ in air

Figure 24. SEM micrographs of the fracture surfaces for Alloy 617 base metal tested at the stress level of $54.1 \mathrm{MPa}$ at $850^{\circ} \mathrm{C}$ in air

Figure 25. SEM micrographs of the fracture surfaces for Alloy 617 weldment tested at a stress level of $63.1 \mathrm{MPa}$ at $850^{\circ} \mathrm{C}$ in air

Figure 25. SEM micrographs of the fracture surfaces for Alloy 617 weldment tested at a stress level of $63.1 \mathrm{MPa}$ at $850^{\circ} \mathrm{C}$ in air

Figure 26. SEM micrographs of the fracture surfaces for Alloy 617 weldment tested at a stress level of $54.1 \mathrm{MPa}$ at $850^{\circ} \mathrm{C}$ in air

Figure 27. SEM micrographs of the fracture surfaces for Alloy 617 base metal tested at the stress level of $28.6 \mathrm{MPa}$ at $950^{\circ} \mathrm{C}$ in air

Figure 28. SEM micrographs of the fracture surfaces for Alloy 617 weldment tested at the stress level of $28.5 \mathrm{MPa}$ at $950^{\circ} \mathrm{C}$ in air

Figure 29. SEM micrographs of the fracture surfaces for Alloy 617 (a) base alloy and (b) weldment tested in air at the stress level of 137.8 and $135 \mathrm{MPa}$ at $750^{\circ} \mathrm{C}$

Figure 30. SEM micrographs of the fracture surfaces for Alloy 617 (a) base alloy and (b) weldment tested in air at the stress level of $24.1 \mathrm{MPa}$ at $950^{\circ} \mathrm{C}$

Figure 31. Optical micrographs of the longitudinal sections of Alloy 617 base metal specimens tested at (a) $750^{\circ} \mathrm{C}, 137.8 \mathrm{MPa}$, (b) $850^{\circ} \mathrm{C}, 54.1 \mathrm{MPa}$, and (c) $950^{\circ} \mathrm{C}, 28.6 \mathrm{MPa}$

Figure 32. Optical micrographs of the longitudinal sections of Alloy 617 weldment specimens tested at (top) $750^{\circ} \mathrm{C}, 135.0 \mathrm{MPa}$ and (bottom) $950^{\circ} \mathrm{C}, 18.5 \mathrm{MPa}$ 


\section{List of Tables}

Table 1. Compositions of Alloy 617 and A508/533 steel............................................. 4

Table 2. Proposed matrix for creep testing of weldment specimens................................ 11

Table 3. Summary of creep test results on base metal and weldments in dry air environment ........................................................................................... 12

Table 4. Additional creep information for Alloy 617 base metal and weldments tested in dry air .................................................................................................. 17 


\section{Creep Rupture Testing of Alloy 617 and A508/533 Base Metal and Weldments}

\section{Introduction}

In the coming decades, the United States and the entire world will need energy supplies to meet the growing demands due to population increase and increase in consumption due to global industrialization. One of the reactor system concepts, the Very High Temperature Reactor (VHTR), with helium as the coolant, has been identified as uniquely suited for producing hydrogen without consumption of fossil fuels or the emission of greenhouse gases (Generation IV 2002). The U.S. Department of Energy (DOE) has selected this system for the Next Generation Nuclear Plant (NGNP) Project, to demonstrate emissions-free nuclear-assisted electricity and hydrogen production within the next 15 years.

The NGNP reference concepts are helium-cooled, graphite-moderated, thermal neutron spectrum reactors with a design goal outlet helium temperature in the range of $750-1000^{\circ} \mathrm{C}$. The reactor core could be either a prismatic graphite block type core or a pebble bed core. The basic technology for the NGNP has been established in the former high temperature gas reactor (HTGR) and demonstration plants (DRAGON, Peach Bottom, AVR, Fort St. Vrain, and THTR). In addition, the technologies for the NGNP are being advanced in the Gas Turbine-Modular Helium Reactor (GT-MHR) project, and the South African state utility ESKOM-sponsored project to develop the Pebble Bed Modular Reactor (PBMR). Furthermore, the Japanese HTTR and Chinese HTR-10 test reactors are demonstrating the feasibility of some of the planned components and materials.

Alloy 617 is a prime candidate for VHTR structural components like reactor internals, piping, and heat exchangers [Natesan et al. 2003, 2006]. Alloy 617 is a nickel-based superalloy having exceptional creep strength at elevated temperatures, especially at temperatures $>800^{\circ} \mathrm{C}$. This alloy contains $\mathrm{Co}, \mathrm{Mo}, \mathrm{Al}$, and $\mathrm{Ti}$ in addition to $\mathrm{Cr}$. Al and $\mathrm{Cr}$ provide the oxidation resistance, while Co and Mo provide the solid solution strengthening. Due to the excellent mechanical properties, oxidation and creep resistance, and phase stability at high temperatures, this alloy is considered a structural material for use in VHTRs. There is a considerable body of work in literature [Natesan, et al. 2006, Osthoff et al. 1984, Schubert et al. 1984, Tanabe et al. 1984, Cook 1984, Schneider et al. 1984] on the creep rupture properties of Alloy 617 for reactor applications. However, there is very little property data on weldments of this alloy.

SA508/SA533 steels are ASME Code approved for Class 1 nuclear components and Subsection NB rules are applicable up to $371^{\circ} \mathrm{C}$ for normal operation. Limited high temperature excursions under off-normal and conduction cooldown conditions are permitted under Code Case N 499. SA-508 forging can be a potential candidate for the RPV design since the peak temperature as calculated by RELAP5 is $\leq 371^{\circ} \mathrm{C}$. The creep performance of SA508/533 steels is being evaluated in air and in helium environments. This report presents primarily the results from the test program on creep behavior of Alloy 617 and base metal and weldments.

\section{Experimental Procedure}

\subsection{Specimen and Material Details}

The creep test specimens used in this study are a button-head design that meets the specifications of ASTM E8 and the fabrication dimensions are shown in Figure 1. The button- 
head creep specimen and associated split-collet grips were selected to prevent specimen retrieval problems associated with galling and seizing caused by high-temperature oxidizing environments on threaded grip designs.

Two lots of creep specimens were fabricated by BEA/INL and supplied to ANL for testing. The first lot of ten specimens was fabricated from a 1.5-inch thick plate of Alloy 617 base metal supplied by ThyssenKrupp VDM USA, Inc. with Cast Heat No. 314626. The second lot of ten weldment specimens was fabricated from two sections of the same ThyssenKrupp Alloy 617 plate v-welded together by GTA process with an Alloy 617 GMAW weld wire supplied by Oxford Alloys, Inc. identified as Heat No. XX3703UK. A schematic illustrating the v-weld location and the adjoining heat affected zones within the creep specimen gage length are shown in Figure 2.

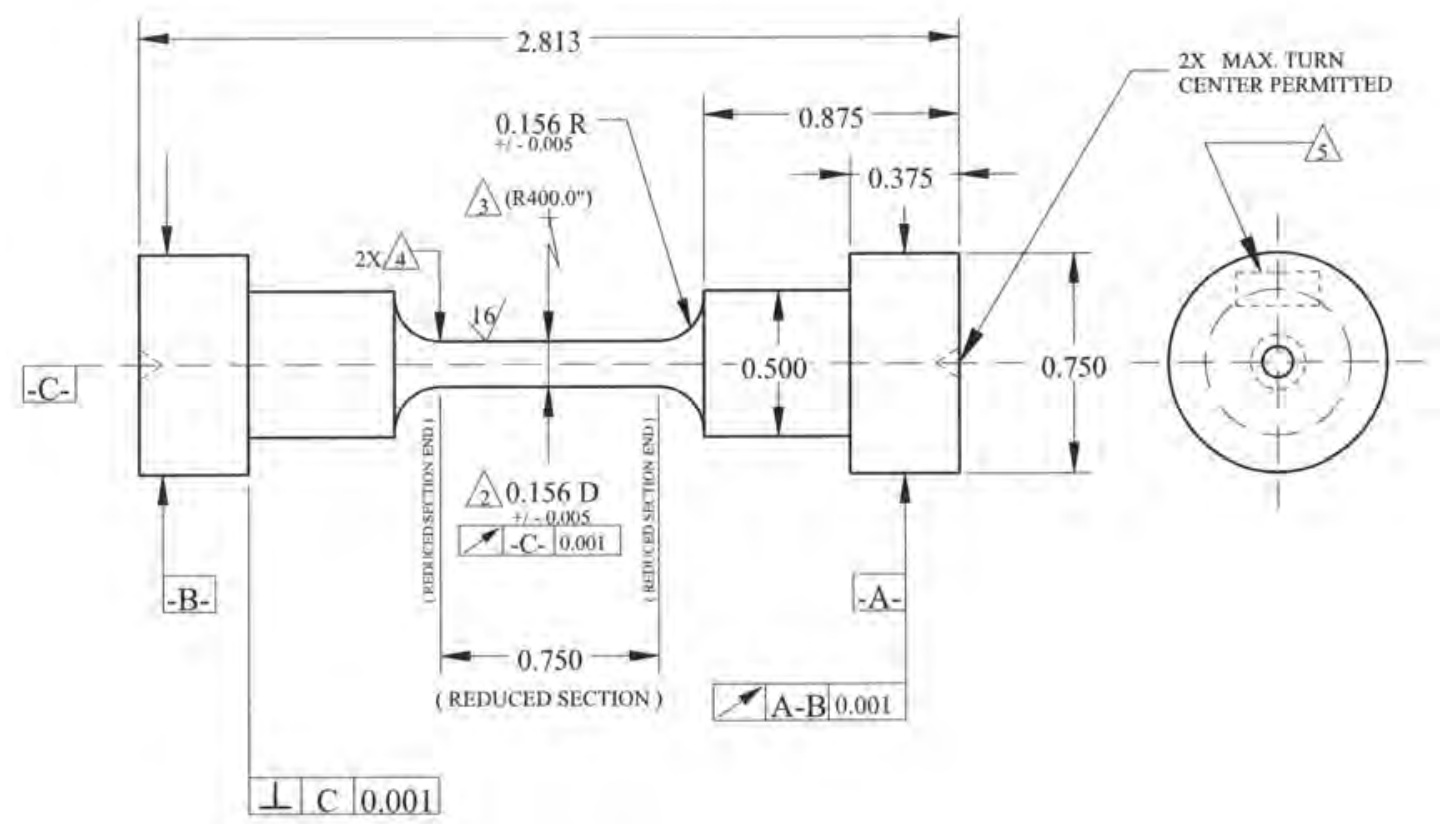

Figure 1. Creep specimen fabrication drawing.

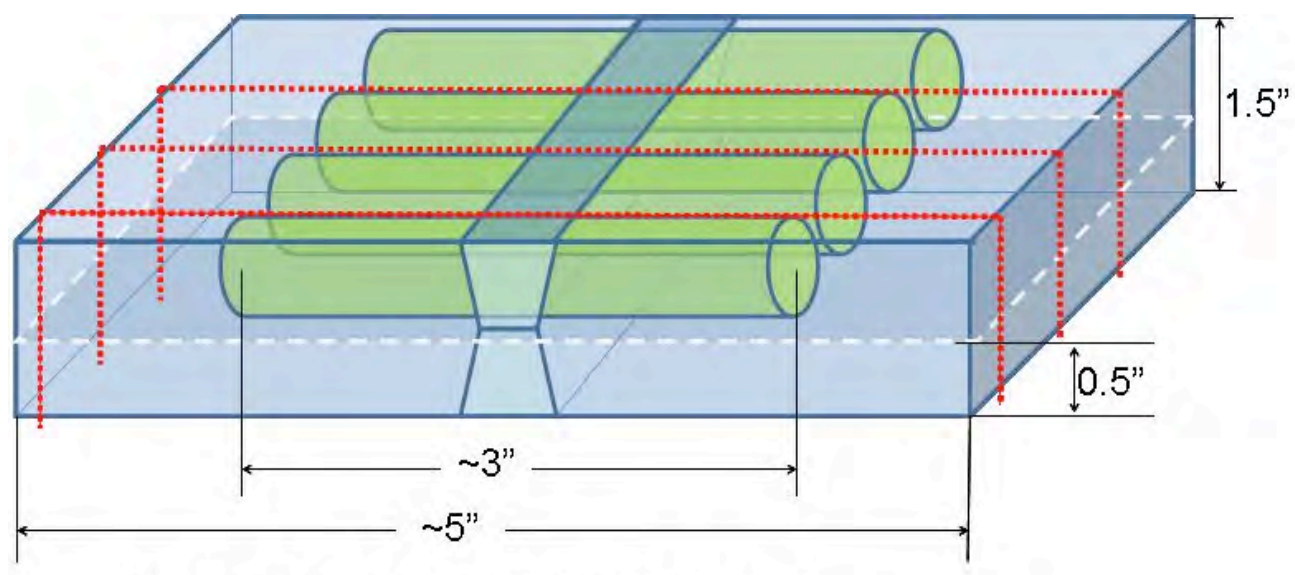

Center button head specimens on weld.

Figure 2. Creep weldment specimen fabrication drawing. 
A weldment specimen (Specimen ID 210-1) that did not meet QA specification because the weld was not centered within the gage length was polished and etched to ascertain the dimensions of the v-weld within the gage length region. Figure 3 is a macro photograph that shows the nominal dimensions of the top and bottom v-weld and a typical hardness profile along the axial direction of the specimen. Table 1 lists the elemental compositions of both Alloy 617 products from the respective supplier's certified material test reports and that of A508/533 steel.
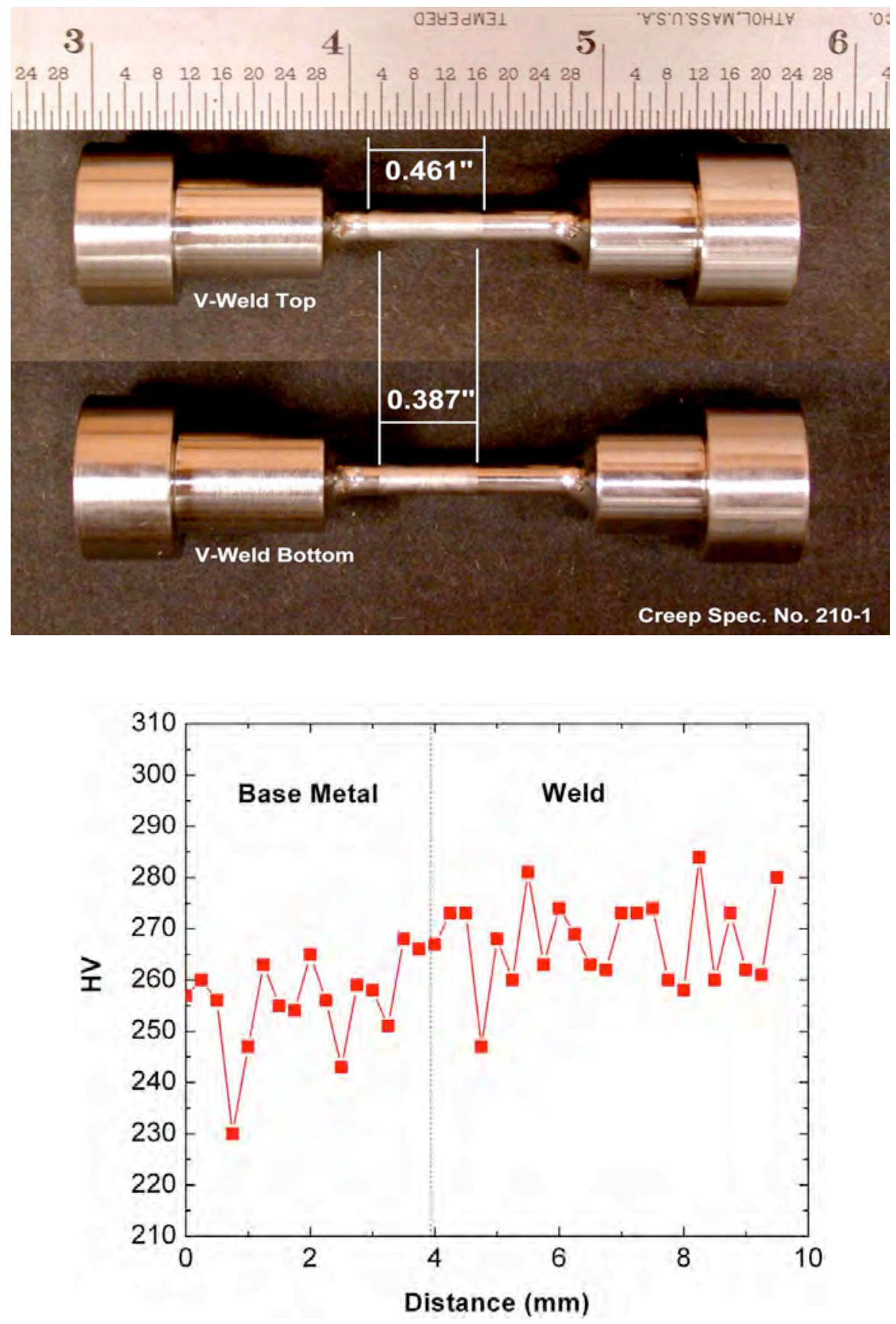

Figure 3. Creep specimen No. 210-1 weld region dimensions and a typical hardness profile along the axial direction of the welded gage section. 


\subsection{Experimental Apparatus}

Currently, six test systems are being utilized for conducting creep/ stress rupture tests. Four test systems based on Applied Test Systems (ATS) Model 2140 direct-load frames, rated at 500 Ibf maximum load capacity, are used for conducting tests on Alloy 617 base metal and weldment specimens in air at temperatures in the range of $750-1000^{\circ} \mathrm{C}$. The low applied stress range of 12-135 MPa for Alloy 617 specimens is well suited for direct-load test frames. The additional two test systems based on Applied Test Systems (ATS) Model 2330 20:1 ratio leverarm indirect-load frames, which are rated at 10,000 lbf maximum load capacity, are used for conducting tests on Alloy A508/533 specimens in air or NGNP He environments at temperatures of $350-390^{\circ} \mathrm{C}$. The higher applied stress range of $414-483 \mathrm{MPa}$ for these specimens necessitates the use of the high load capacity of the lever-arm indirect-loading frames.

The four direct-load test systems contain the following like components: an ATS Model 2961 three-zone split furnace rated at $1200^{\circ} \mathrm{C}$; an ATS Model 2634 temperature control system incorporating manual fine-tuning adjustable zone SCRs slaved to a Love Controls, Inc. Model 16A digital auto-tuning process controller; a 3-in. diameter by 24-in. long alumina tube retort chamber with water-cooled ported end-caps for environmental control and load train feedthrough; two Type-K 0.030-in. diameter Inconel clad thermocouples by Omega Engineering, Inc.; a Jenco, Inc. Model 765 digital thermocouple display; a Schaevitz/Lucas Model 500HR LVDT extensometer with an associated Model ATA2001 output signal conditioner; a Honeywell

Table 1. Compositions of Alloy 617 and A508/533 steel

\begin{tabular}{|c|c|c|c|}
\hline \multirow[b]{2}{*}{ Element } & \multicolumn{2}{|c|}{ Alloy 617} & \multirow{2}{*}{$\begin{array}{c}\text { A508/533 steel } \\
\text { Industeel/ArcelorMittal } \\
\text { 7-in. thick plate } \\
\text { (wt. \%) }\end{array}$} \\
\hline & $\begin{array}{c}\text { ThyssenKrupp VDM USA, Inc. } \\
\text { 1.5-in. thick plate } \\
\text { (wt. \%) }\end{array}$ & $\begin{array}{l}\text { Oxford Alloys, Inc. 0.045-in. dia } \\
\text { weld wire } \\
\text { (wt. } \%)\end{array}$ & \\
\hline $\mathrm{Ni}$ & 54.1 & 53.91 & 0.62 \\
\hline $\mathrm{Cr}$ & 22.2 & 22.41 & 0.18 \\
\hline Co & 11.6 & 11.49 & - \\
\hline Mo & 8.6 & 8.98 & 0.51 \\
\hline $\mathrm{Fe}$ & 1.6 & 1.37 & Bal. \\
\hline $\mathrm{Al}$ & 1.1 & 1.10 & 0.025 \\
\hline $\mathrm{Ti}$ & 0.4 & 0.34 & 0.002 \\
\hline $\mathrm{Mn}$ & 0.1 & 0.11 & 1.43 \\
\hline $\mathrm{Cu}$ & 0.04 & 0.04 & 0.11 \\
\hline $\mathrm{Si}$ & 0.1 & 0.04 & 0.22 \\
\hline C & 0.05 & 0.089 & 0.18 \\
\hline$S$ & $<0.002$ & 0.001 & 0.001 \\
\hline B & $<0.001$ & - & 0.0002 \\
\hline$P$ & - & 0.005 & 0.006 \\
\hline V & - & - & 0.002 \\
\hline $\mathrm{Ca}$ & - & - & 0.0001 \\
\hline $\mathrm{Nb}$ & - & - & 0.001 \\
\hline
\end{tabular}


Model DPR100 dual channel strip chart recorder; and a PC computer data acquisition system for logging extensometer transducer output. An overall view of the direct-load creep systems used for conducting tests in air at temperatures of $750-1000^{\circ} \mathrm{C}$ is shown in Figure 4.

The two ATS indirect-load lever-arm test systems contain all of the same or similar components previously described for the direct-load systems with the addition of an Interface, Inc. Model 1010-ACK 2500-lbf load cell in-line with the load train. The load cell and conditioner/ monitor system is interfaced to the PC computer data acquisition system and allows for accurate verification of applied stress parameters as well as monitoring initial loading rate at the start of a test. An overall view of the two indirect-load creep systems used for conducting tests in air or NGNP He environments is shown in Figure 5.

A schematic and detailed view of the load train with creep specimen, split collet button-head grips, specimen temperature monitoring thermocouples, pull rods positioned within the threezone furnace and retort tube assembly is shown in Figure 6. Each heat zone of the furnace is 4 in. long and the test specimen is centered within the middle zone. An auto-tuning digital process controller that monitors the temperature of the center zone maintains the desired creep test temperature. The creep specimen temperature profile during testing is controlled by adjustments to the top and bottom heat zones via fine tuning SCR power controllers for these respective zones. All the SCR power circuits are slaved to the main process controller. The resulting specimen temperature profile is verified by two calibrated thermocouples that are spotwelded to the specimen top and bottom transition radius ends approximately 1.06 in. apart. The temperatures to establish the profiles are continuously monitored by digital temperature displays and a strip chart recorder.

Gaseous environmental conditions within the retort are achieved by supplying a gas of known composition through a series of high-pressure and low-pressure regulators into a common supply manifold. The gas within the manifold is directed through a flow-rate-metering valve at the bottom port of the retort end-cap seal and a gauge on the supply manifold assembly monitors the gas pressure within the retort. The flowing environmental gas exits the retort chamber at the top end-cap seal port through a bubbler that prevents atmospheric back streaming. An LVDT axial strain extensometer is attached to the load train external to the retort and has a linear displacement of $1 \mathrm{in.}$ The extensometer conditioner provides a corresponding linear high-level voltage output of $0-10 \mathrm{Vdc}$ with a resolution of $\leq 0.02 \%$ strain. 


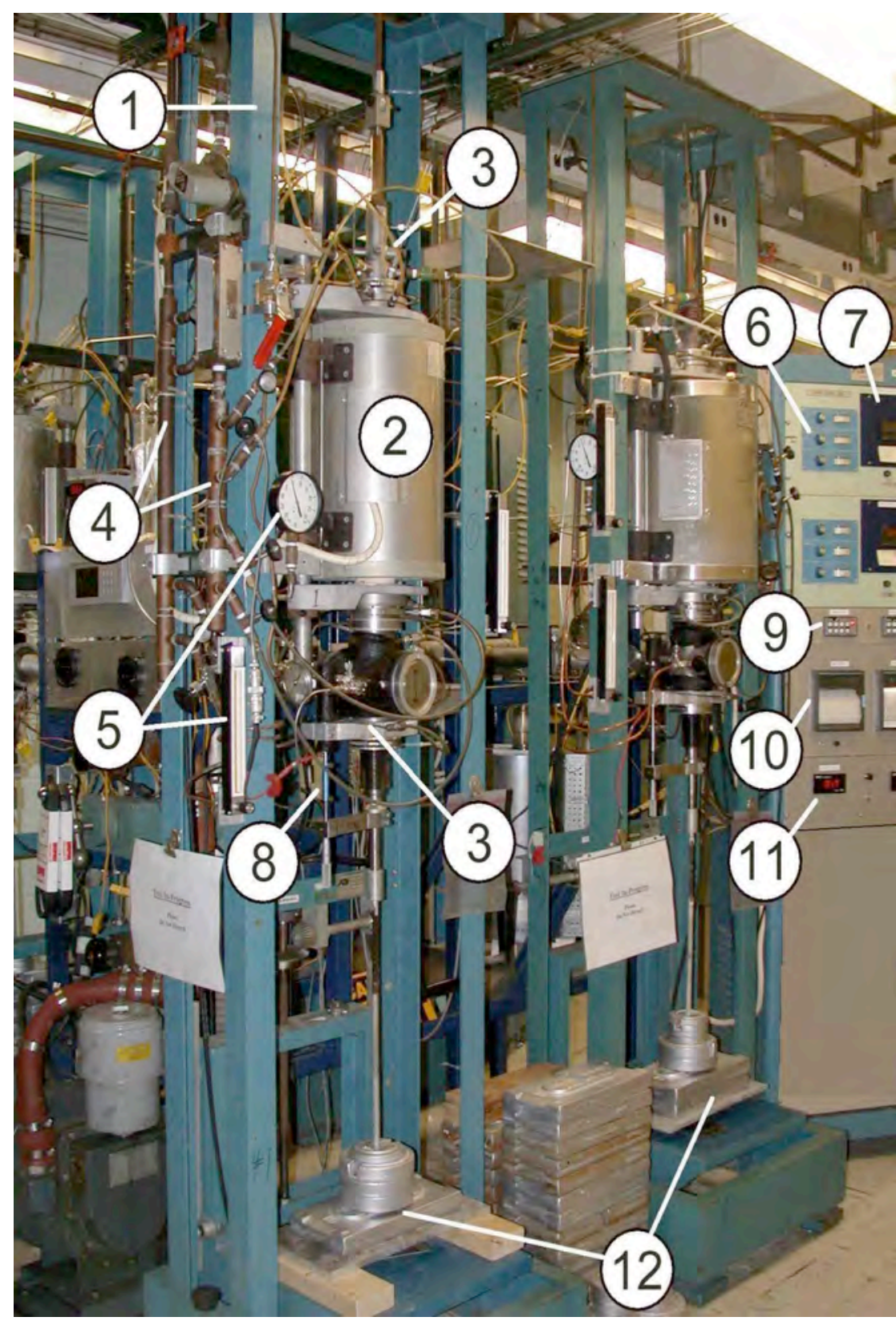

1. ATS Direct-Load Test Frame

2. ATS 3-Zone Furnace

3. Alumina Retort Chamber Assembly

4. Retort End-Cap WaterCooling Manifold

5. Retort Gas Environment Control Manifold

6. Furnace 3-Zone Fine Tuning Controls

7. Furnace Temperature Controller

8. LVDT Extensometer

9. LVDT Conditioner

10. Strip Chart Recorder

11. Specimen Temperature Digital Indicator

12. Creep Force DeadWeight Plates and Loading Pan

Figure 4. Overall view of direct-load creep test facility for air and gas environments. 


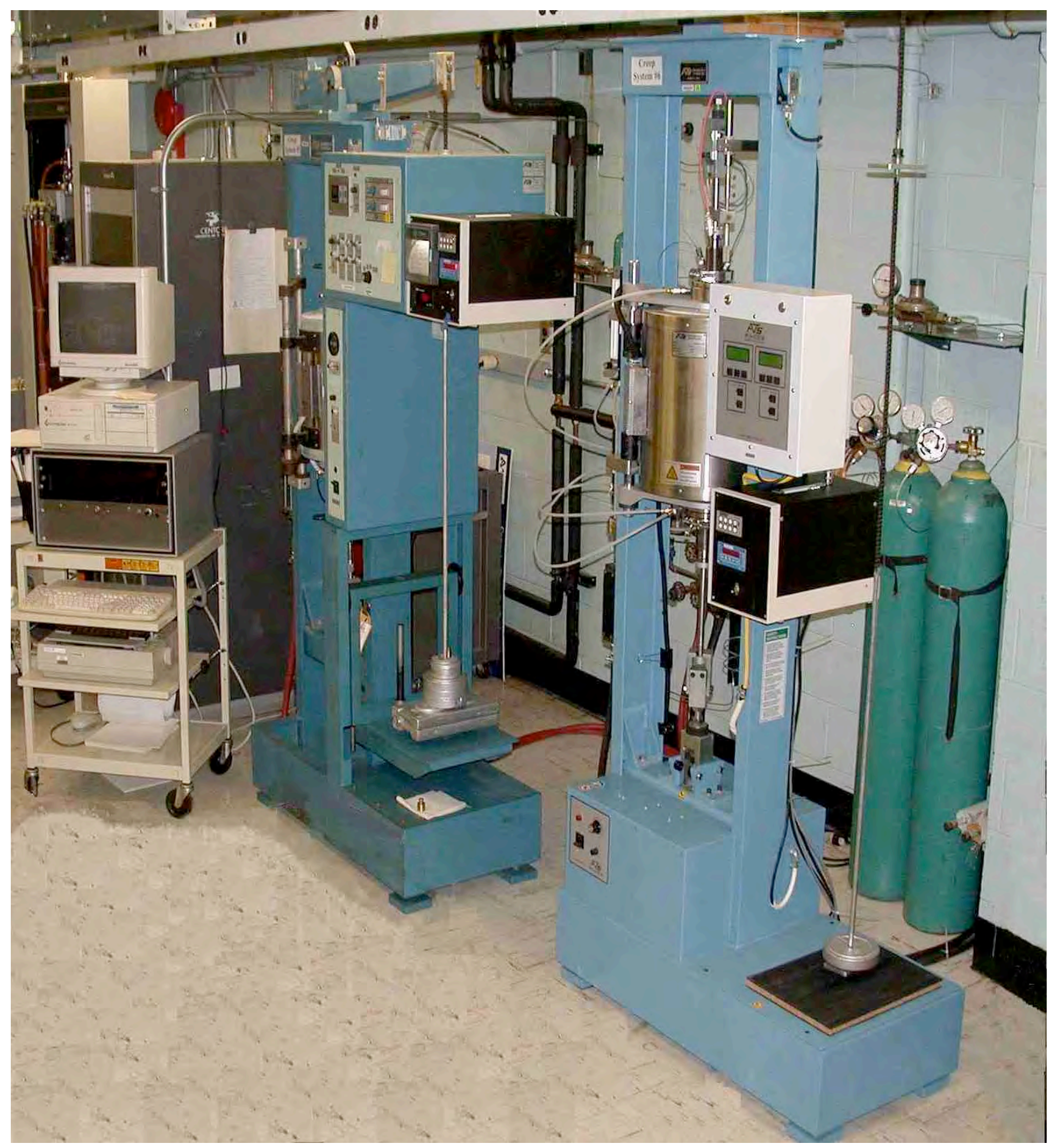

Figure 5. Overall view of lever-arm creep test facility for air and gas environments. 


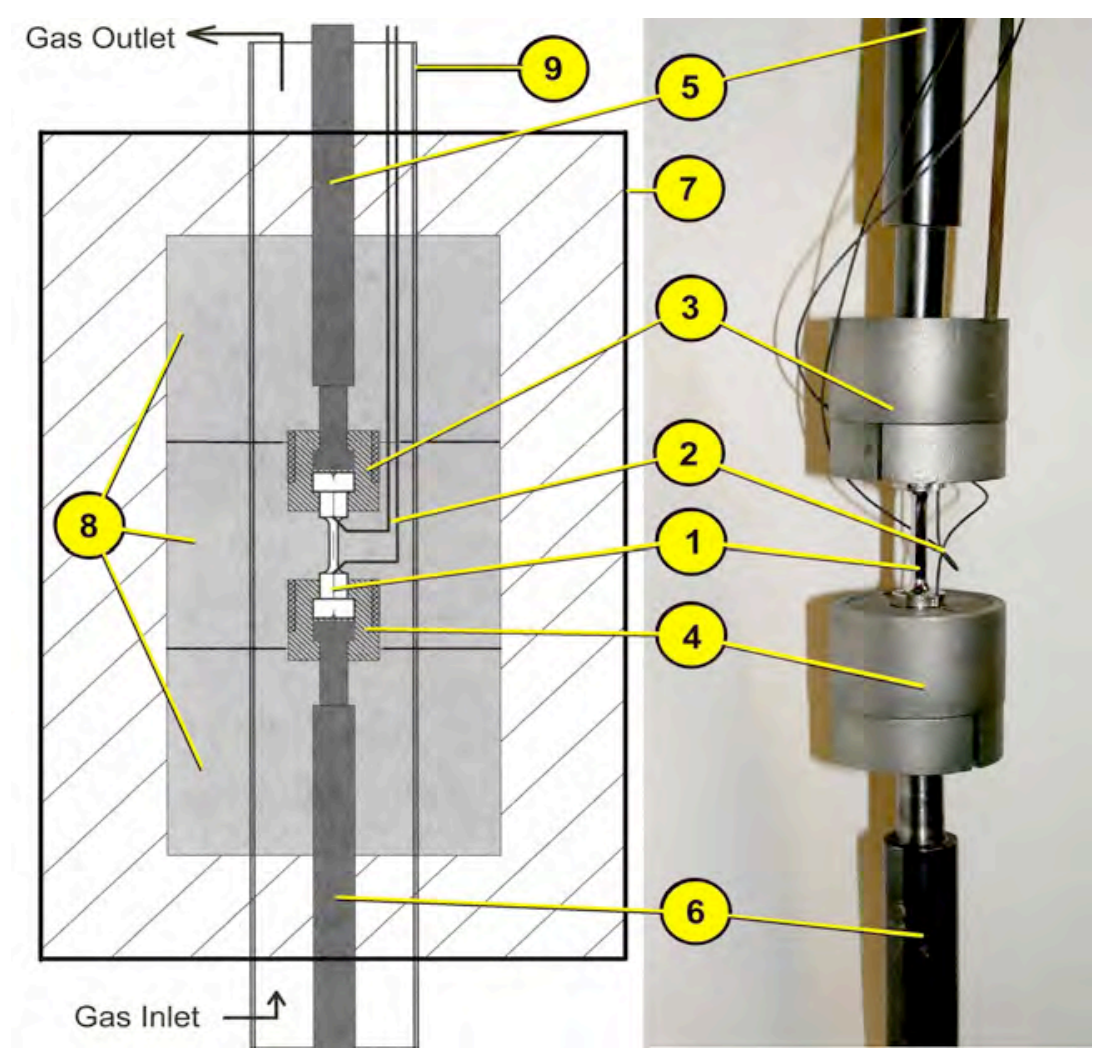

1. Creep Test Specimen

2. Specimen Temperature Monitoring Thermocouples

3. Top Split-Collet Grip

4. Bottom Split-Collet Grip

5. Top Pull Rod -Fixed

6. Bottom Pull Rod Movable

7. Furnace Chamber

8. Three-Zone Heating Elements

9. Alumina Retort Tube

Figure 6. Schematic and detail views of creep specimen load train.

\subsection{Creep Test Procedure}

Prior to creep testing, all specimens are inspected with a calibrated 50X optical comparator to verify dimensions meet ASTM E8 fabrication requirements. Specimens are then subject to examination under a 3X-stereo microscope for any defects in the gage length region. Following visual inspection, the gage length and shoulder regions of each specimen are polished with 1200-grit SiC lapping paper to a $\mathrm{Ra} \leq 10 \mu \mathrm{m}$ finish. Polishing is performed in the axial direction to alleviate crack initiation sites due to circumferential machining scratches. A final visual inspection is then performed via the optical comparator to record initial test specimen dimensions. Test specimens are then ultrasonically cleaned in a methanol/ acetone bath.

The creep specimen is loaded into the split-collet grips and pull rod assembly supported by a setup jig. Calibrated thermocouples are spot welded to the specimen outer transition radius shoulder edge so as not to introduce defects into the gage length area. The Inconel clad thermocouples are 0.030 -inch diameter with an ungrounded junction, and are installed through sealing ports of the retort top end-cap.

The specimen load train assembly is loaded into the furnace retort chamber with the test specimen centered in the middle heat zone for both types of creep test frames. For the directload creep frames, the upper pull rod is attached to the creep load frame top fixed-crosshead by a pinned gimbal alignment fixture, and all the feedthroughs in the top end-cap seal are secured. The bottom end-cap seal is then installed and secured to the retort. The bottom end-cap contains a flexible stainless steel bellows assembly that permits motion of the lower pull rod and dead-weight load pan assembly. Once vertical axial alignment of the load train is obtained, the 
LVDT extensometer is attached to the lower pull rod assembly.

For the lever-arm indirect-load creep frames, the upper pull rod is attached to the creep load frame movable top lever-arm by a gimbaled clevis grip attached to a load cell. The in-line load cell in turn is connected to the lever-arm through a knife-edge alignment fixture, and all feedthroughs in the top end-cap seal/ bellows assembly are secured. The lower pull rod is then inserted through the bottom end-cap/ bellows assembly and secured to the retort bottom flange. The lower pull rod is next attached to the fixed crosshead in the base of the frame through a matching gimbaled clevis grip. Once vertical axial alignment of the load train is obtained and the lever-arm is balanced horizontally, the LVDT extensometer is attached to the upper pull rod assembly and the load cell is null balanced for zero output.

The LVDT extensometer and signal conditioner assembly is calibrated before and after the start of each creep test. The calibration is performed using a Schaevitz Model PMB1000U micrometer gage-head fixture. Corresponding extensometer output voltages obtained during the LVDT displacement calibration are measured with a precision digital voltmeter. Both the micrometer gage-head fixture and precision voltmeter have been calibrated to NIST traceable standards.

The total applied force exerted on the cross-section area of the specimen gage section determines the applied stress value, required for each creep test. For the direct-load creep system, the total applied force is the sum of the component weights from the load train (lower pull rod and grip), extensometer assembly, weight pan assembly, and dead-weight plate stack. The weights of the specimen grip, pull rod, and extensometer assembly are independently measured with a digital mass balance. The combined dead-weight plate stack and weight pan assembly is measured with a calibrated load cell test stand. The digital mass balance and the load cell are calibrated to NIST traceable standards with accuracies of \pm 0.001 and $\pm 0.1 \mathrm{lbf}$, respectively. The desired amount of dead-weight plates is loaded onto the weight pan assembly, which is positioned in the unloaded state. Only the weight of the lower pull rod, grip, and extensometer assembly are acting on the specimen during heat up and prior to full loading. The weight of these combined components is $\approx 13 \mathrm{lbf}$ producing a preload stress of $\approx 4.7 \mathrm{MPa}$. This preload helps maintain load train alignment.

For the indirect-load creep system, the total applied force is the sum of the dead weights on the lever-arm weigh pan multiplied by the 20:1 cantilever ratio. The component weights of the pull rods and grips are nulled out by an adjustable counterbalance weight mounted in the lever-arm. The combined dead-weight plate stack is measured with a calibrated load cell test stand and the load train in-line load cell monitoring system. The test stand and in-line load cells are calibrated to NIST traceable standards with accuracies of $\pm 0.1 \mathrm{lbf}$.

The retort gas environment is configured to supply a flowing dry air. The supply gas is contained in a compressed gas cylinder with an initial volume of 238 cubic feet and pressure of 2200 psig. The composition is $20-22 \%$ oxygen, balance nitrogen, and moisture content of $<7$ ppm by volume. Gas from the supply cylinder passes through a pressure reducing two-stage regulator and then to a low-pressure regulator feeding the retort manifold. The gas supply manifold connected to the retort chamber is set for a delivery pressure of 3 psig and a flow rate of $10 \mathrm{cc} / \mathrm{min}$. After the gas environment has been set, the cooling water manifold is activated to provide cooling for the retort end-cap seals.

A three-zone furnace is used to heat the retort chamber and an auto-tune process controller is used to adjust the heat input. The controller is programmed to reach the test temperature set 
point over a three-hour ramp time. Once the retort chamber temperature has reached set point temperature, a hold-time period is initiated. The hold-time allows for fine-tuning the zone control SCRs so the specimen temperature profile is maintained within $\pm 1^{\circ} \mathrm{C}$ of the desired test temperature, and provides adequate time so the thermal expansion of the specimen load train has reached a quiescent steady state. Thermal expansion equilibrium is determined by monitoring the extensometer output on the strip chart recorder. Hold-times are typically $\approx 20$ hours in duration.

At completion of the hold-time, the computer data logging system is initiated and the creep test is started by manually lowering the weight pan assembly containing the dead-weight plate stack. The data-logging interval of the extensometer output is controlled by a rate-change algorithm or by operator intervention. The creep test is completed when the specimen ruptures, that results in the weight pan assembly contacting a proximity switch. The switch action provides a synchronizing marker-pulse to the data-logging computer and shuts off power to the furnace retort system, providing automatic cool-down.

At the conclusion of the creep test, the specimen and load train assembly are removed from the retort chamber for specimen examination. The 50x optical comparator is used to measure fracture location, fracture diameter, and gage length elongation. The specimen is then sectioned for SEM analysis.

\section{Creep Test Results}

During the past year, several creep tests have been completed and several additional tests are in progress. Of the completed tests, eight were conducted on Alloy 617 base metal specimens and nine were on Alloy 617 weldments. The test temperatures ranged between 750 and $950^{\circ} \mathrm{C}$. Table 2 lists the planned matrix for creep tests on Alloy 617 weldment specimens. The tests on base metal specimens generally followed the same test parameters as those for weldment tests. Table 3 summarizes the results from tests that were completed and for those in progress.

\subsection{Creep Data}

Figure 7 shows the creep strain versus elapsed time plots for base Alloy 617 and a weld sample tested at an applied stress of $135-137.8 \mathrm{MPa}$ at $750^{\circ} \mathrm{C}$. As in the previous studies on creep of base Alloy 617, the present data also indicate a small period of second-stage (linear creep rate) creep. The rupture strains for the base alloy and the weldment were 27 and 12.9\%, respectively. Figure 8 shows the creep strain versus elapsed time plots for two weld samples tested at applied stresses of 135 and $118 \mathrm{MPa}$ at $750^{\circ} \mathrm{C}$. As expected, the creep rupture life is longer at the lower applied stress; however, the rupture strains for both specimens were similar at $\approx 13 \%$.

Figures 9 and 10 show a comparison of the creep behavior of the base Alloy 617 and the weldment tested at $850^{\circ} \mathrm{C}$ at applied stress levels of $\approx 43$ and $\approx 54 \mathrm{MPa}$. These preliminary data indicate that the rupture lives of weld specimens are much longer than those for the base alloy, when tested under identical test conditions. On the other hand, the rupture strains for the weld specimens are much smaller than those for the base alloy specimens, tested under identical conditions. Figure 11 shows the creep curves for duplicate tests on base Alloy 617 and weldments at $850^{\circ} \mathrm{C}$ at applied stress levels of $61.3-63.1 \mathrm{MPa}$. It is clear from all these tests that the creep strain at fracture is in the range of $12-18 \%$ for weldment specimens and are much lower than those for base alloy, under similar test conditions. 
Table 2. Proposed matrix for creep testing of weldment specimens*

\begin{tabular}{|c|c|c|c|c|c|}
\hline $\begin{array}{c}\text { Spec. } \\
\#\end{array}$ & $\begin{array}{c}\text { Test } \\
\text { Temperature } \\
\left({ }^{\circ} \mathrm{C}\right)\end{array}$ & $\begin{array}{c}\text { Applied } \\
\text { Stress (MPa) }\end{array}$ & $\begin{array}{l}\text { Estimated } \\
\text { Rupture Time (h) }\end{array}$ & $\begin{array}{l}\text { Estimated } 95 \% \\
\text { Lower Bound } \\
\text { Rupture Time }(\mathrm{h})\end{array}$ & $\begin{array}{l}\text { Estimated 95\% } \\
\text { Upper Bound } \\
\text { Rupture Time (h) }\end{array}$ \\
\hline 1 & 750 & 135.0 & 1349 & 167 & 2531 \\
\hline 2 & 750 & 135.0 & 1349 & 167 & 2531 \\
\hline 3 & 750 & 118.0 & 3107 & 385 & 5830 \\
\hline 4 & 750 & 118.0 & 3107 & 385 & 5830 \\
\hline 5 & 750 & 95.0 & 11911 & 1475 & 22347 \\
\hline 6 & 750 & 95.0 & 11911 & 1475 & 22347 \\
\hline 7 & 850 & 63.0 & 1349 & 181 & 2518 \\
\hline 8 & 850 & 63.0 & 1349 & 181 & 2518 \\
\hline 9 & 850 & 54.0 & 3169 & 424 & 5914 \\
\hline 10 & 850 & 54.0 & 3169 & 424 & 5914 \\
\hline 11 & 850 & 43.0 & 11158 & 1494 & 20822 \\
\hline 12 & 850 & 43.0 & 11158 & 1494 & 20822 \\
\hline 13 & 950 & 28.5 & 1357 & 194 & 2520 \\
\hline 14 & 950 & 28.5 & 1357 & 194 & 2520 \\
\hline 15 & 950 & 24.0 & 3198 & 457 & 5939 \\
\hline 16 & 950 & 24.0 & 3198 & 457 & 5939 \\
\hline 17 & 950 & 18.5 & 11825 & 1689 & 21960 \\
\hline 18 & 950 & 18.5 & 11825 & 1689 & 21960 \\
\hline 19 & 1000 & 19.0 & 1341 & 197 & 2485 \\
\hline 20 & 1000 & 19.0 & 1341 & 197 & 2485 \\
\hline 21 & 1000 & 16.0 & 3031 & 446 & 5617 \\
\hline 22 & 1000 & 16.0 & 3031 & 446 & 5617 \\
\hline 23 & 1000 & 12.0 & 11871 & 1745 & 21997 \\
\hline 24 & 1000 & 12.0 & 11871 & 1745 & 21997 \\
\hline
\end{tabular}

${ }^{*}$ All the welds were made by gas-tungsten-arc welding process using Alloy 617 plate (Heat \#314626) and Alloy 617 consumable weld metal (Heat \# XX3703UK).

Figures 12-14 show a comparison of the creep behavior of the base Alloy 617 and the weldment, tested at $950^{\circ} \mathrm{C}$ at applied stress levels of $28.5,24.1$, and $18.5 \mathrm{MPa}$, respectively. In general, the creep performance of the base alloy and the weldment at $950^{\circ} \mathrm{C}$ was similar to those observed at $850^{\circ} \mathrm{C}$. In most of the welded specimens, the creep fracture occurred in the vicinity of the heat-affected zone of the specimens, except in the specimen tested at $18.5 \mathrm{MPa}$ in which the fracture occurred in weld zone of the specimen. This is reflected in the lower rupture strain of $7.1 \%$ and lower reduction in area of $3.3 \%$ in the specimen tested at $18.5 \mathrm{MPa}$, when compared with those obtained in other specimens tested at the same temperature. 
Table 3. Summary of creep test results on base metal and weldments in dry air environment

\begin{tabular}{|c|c|c|c|c|c|c|c|}
\hline $\begin{array}{l}\text { Specimen } \\
\text { ID }\end{array}$ & $\begin{array}{l}\text { Alloy } 617 \\
\text { Specimen } \\
\text { Type }\end{array}$ & $\begin{array}{c}\text { Test } \\
\text { Temperature } \\
\left({ }^{\circ} \mathrm{C}\right)\end{array}$ & $\begin{array}{l}\text { Applied } \\
\text { Stress } \\
\text { (MPa) }\end{array}$ & $\begin{array}{l}\text { Rupture } \\
\text { Time } \\
\text { (h) }\end{array}$ & $\begin{array}{c}\text { Rupture } \\
\text { Strain } \\
(\%)\end{array}$ & $\begin{array}{c}\text { Reduction } \\
\text { in Area } \\
(\%)\end{array}$ & $\begin{array}{c}\text { Creep Rate } \\
\quad(\% / h)\end{array}$ \\
\hline $\mathrm{H} 3$ & Base Metal & 750 & 137.8 & 1470.0 & 27.0 & 36.5 & $3.20 \times 10^{-03}$ \\
\hline $\mathrm{H} 1$ & Base Metal & 850 & 63.1 & 275.1 & 46.0 & 50.4 & $9.49 \times 10^{-02}$ \\
\hline $\mathrm{H} 8$ & Base Metal & 850 & 63.0 & 260.9 & 52.3 & 53.6 & $1.13 \times 10^{-01}$ \\
\hline $\mathrm{H} 7$ & Base Metal & 850 & 43.1 & 1115.3 & 38.7 & 39.1 & $2.15 \times 10^{-02}$ \\
\hline $\mathrm{H} 4$ & Base Metal & 850 & 54.1 & 394.4 & 41.5 & 48.7 & $7.11 \times 10^{-02}$ \\
\hline $\mathrm{H} 2$ & Base Metal & 950 & 28.6 & 561.8 & 40.4 & 36.5 & $4.41 \times 10^{-02}$ \\
\hline $\mathrm{H} 5$ & Base Metal & 950 & 24.1 & 956.6 & 56.9 & 35.5 & $2.75 \times 10^{-02}$ \\
\hline $617-1$ & Base Metal & 950 & 18.5 & $3898.7^{* *}$ & $26.1^{* \star}$ & $13.4^{* *}$ & $4.23 \times 10^{-03}$ \\
\hline $210-06$ & Weldment & 750 & 135.0 & 2794.9 & 12.9 & 29.8 & $8.32 \times 10^{-04}$ \\
\hline 210-09 & Weldment & 750 & 118.0 & 5953.4 & 13.0 & 16.8 & $4.35 \times 10^{-04}$ \\
\hline $210-10$ & Weldment & 750 & 95.0 & $3825.0^{*}$ & - & - & $8.40 \times 10^{-05}$ \\
\hline $210-02$ & Weldment & 850 & 61.3 & 1332.4 & 18.2 & 41.5 & $2.85 \times 10^{-02}$ \\
\hline 617-W1 & Weldment & 850 & 62.9 & 936.4 & 14.3 & 30.3 & $2.07 \times 10^{-03}$ \\
\hline $210-03$ & Weldment & 850 & 54.0 & 1648.6 & 13.6 & 33.4 & $1.73 \times 10^{-03}$ \\
\hline 617-W2 & Weldment & 850 & 54.0 & $2050.0^{*}$ & - & - & $1.29 \times 10^{-03}$ \\
\hline $210-07$ & Weldment & 850 & 43.0 & 3226.3 & 11.6 & 30.7 & $6.00 \times 10^{-04}$ \\
\hline $210-04$ & Weldment & 950 & 28.5 & 871.1 & 13.8 & 16.7 & $8.18 \times 10^{-03}$ \\
\hline 210-05 & Weldment & 950 & 24.1 & 2093.8 & 13.7 & 16.9 & $8.98 \times 10^{-03}$ \\
\hline $210-08$ & Weldment & 950 & 18.5 & 4484.5 & 7.1 & 3.3 & $3.00 \times 10^{-03}$ \\
\hline $\mathrm{A} 01$ & Alloy A508 & 390 & 413.7 & $5125.0^{*}$ & - & - & $2.33 \times 10^{-04}$ \\
\hline
\end{tabular}

*in progress; ${ }^{* *}$ terminated prior to specimen fracture due to furnace failure. 

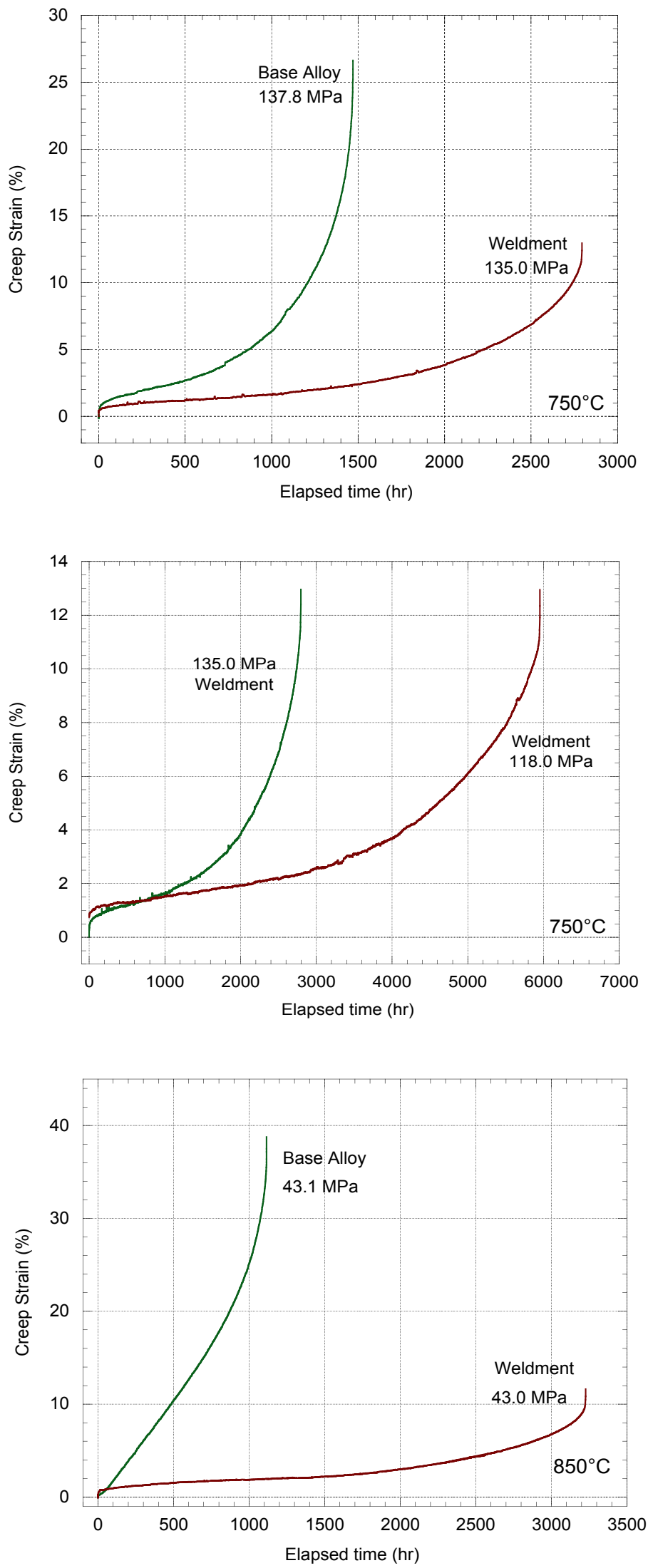

Figure 7. A comparison of the creep behavior of base metal and weldment of Alloy 617 , tested at $750^{\circ} \mathrm{C}$.

Figure 8. Creep behavior of weldment of Alloy 617 tested at $750^{\circ} \mathrm{C}$ and at two applied stress levels.

Figure 9. A comparison of the creep behavior of base metal and weldment of Alloy 617 tested at $850^{\circ} \mathrm{C}, \sim 43 \mathrm{MPa}$. 

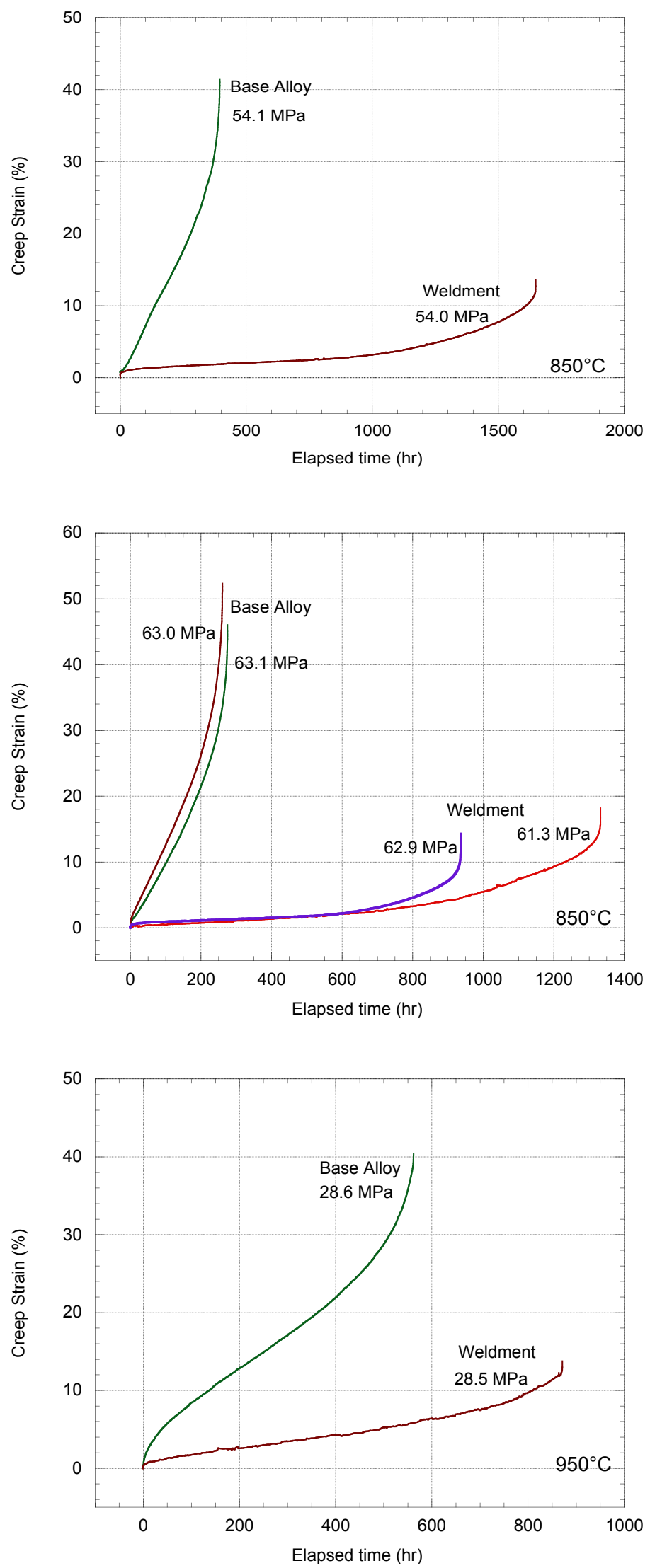

Figure 10. A comparison of the creep behavior of base metal and weldment of Alloy 617 tested at $850^{\circ} \mathrm{C}, \sim 54 \mathrm{MPa}$.
Figure 11. A comparison of the creep behavior of base metal and weldment of Alloy 617 tested at $850^{\circ} \mathrm{C}, \sim 61.3-$ 63.1 MPa.
Figure 12. A comparison of the creep behavior of base metal and weldment of Alloy 617 tested at $950^{\circ} \mathrm{C}, \sim 28.5$ $\mathrm{MPa}$. 

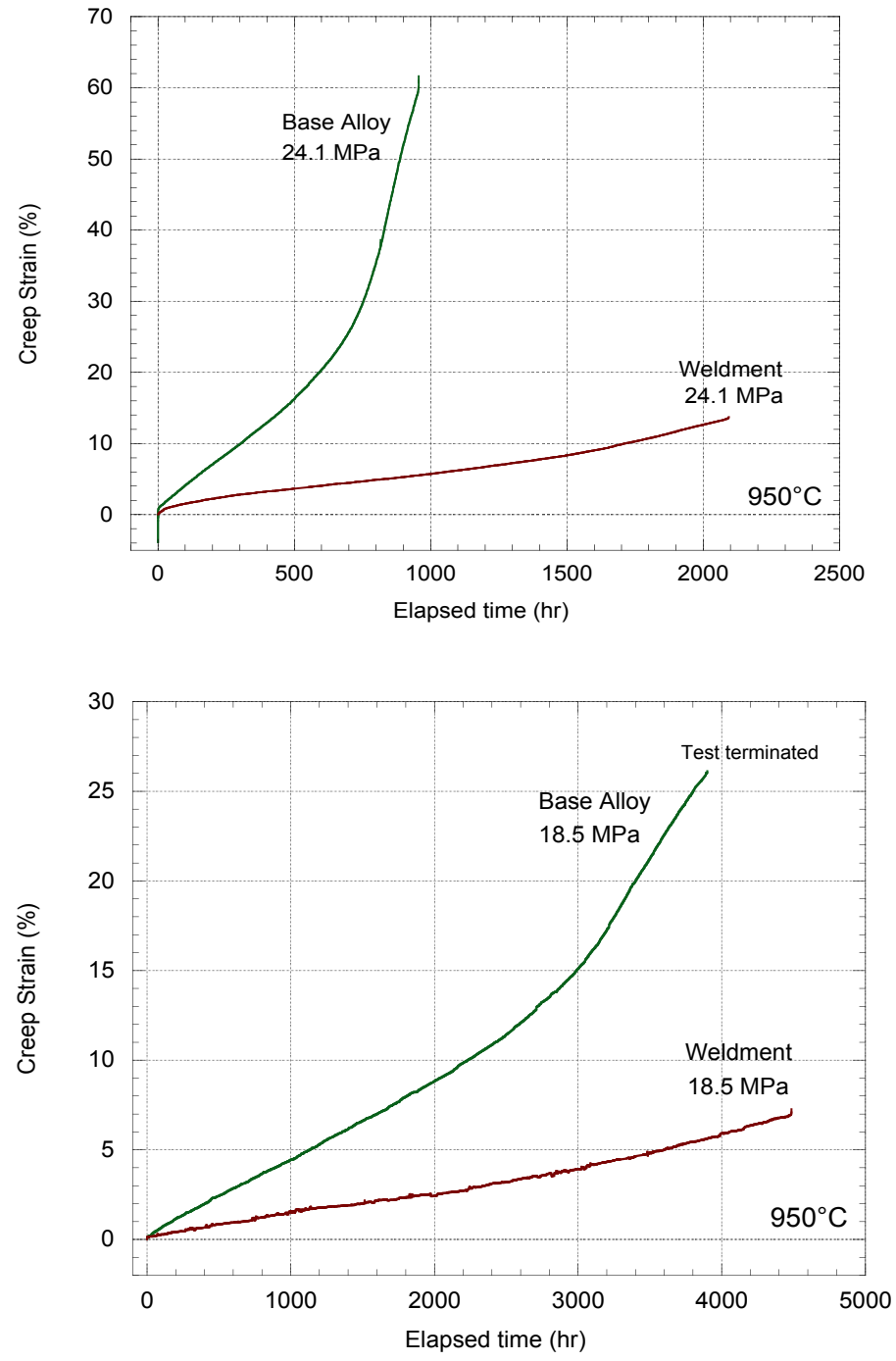

Figure 13. A comparison of the creep behavior of base metal and weldment of Alloy 617 tested at $950^{\circ} \mathrm{C}, 24.1$ MPa.

Figure 14. A comparison of the creep behavior of base metal and weldment of Alloy 617 tested at $950^{\circ} \mathrm{C}, 18.5$ $\mathrm{MPa}$.

\subsection{Creep Rate Analysis}

The creep behavior of Alloy 617 is somewhat different from that of the conventional steels such as carbon steel, low alloy steels, $9 \mathrm{Cr}-1 \mathrm{Mo}$ steel, and austentic stainless steels. While the steels show distinct primary, secondary (or linear steady state), and tertiary creep regimes, the Alloy 617 seems to exhibit predominantly accelerated creep rate from the start which is essentially a third stage creep. The creep curves developed in this program were used to examine (1) if a secondary creep rate can be developed and if so, (2) can we establish the onset of tertiary creep at various temperatures and applied stresses.

Figure 15 shows plots of creep strain rates versus time, calculated from the creep curves for some of the tests conducted at 750,850 , and $950^{\circ} \mathrm{C}$ on base metal and weldment specimens of Alloy 617 . The results indicate that one can infer some steady state (approximately constant region in creep rate versus time curves in Fig. 15) creep rate for some portion of each test. In general, the weldment specimens showed more of a flat or constant creep rate region than the base metal specimens. Table 4 lists the time ranges that were used in the calculation of the 
creep rate and the last column in the table gives the ratio of the time-to-onset of tertiary to the rupture time for all the tests conducted. In general, the base alloy and the weldment exhibit tertiary creep after $50-60 \%$ of the rupture life, irrespective of test temperature in the range of $750-950^{\circ} \mathrm{C}$.
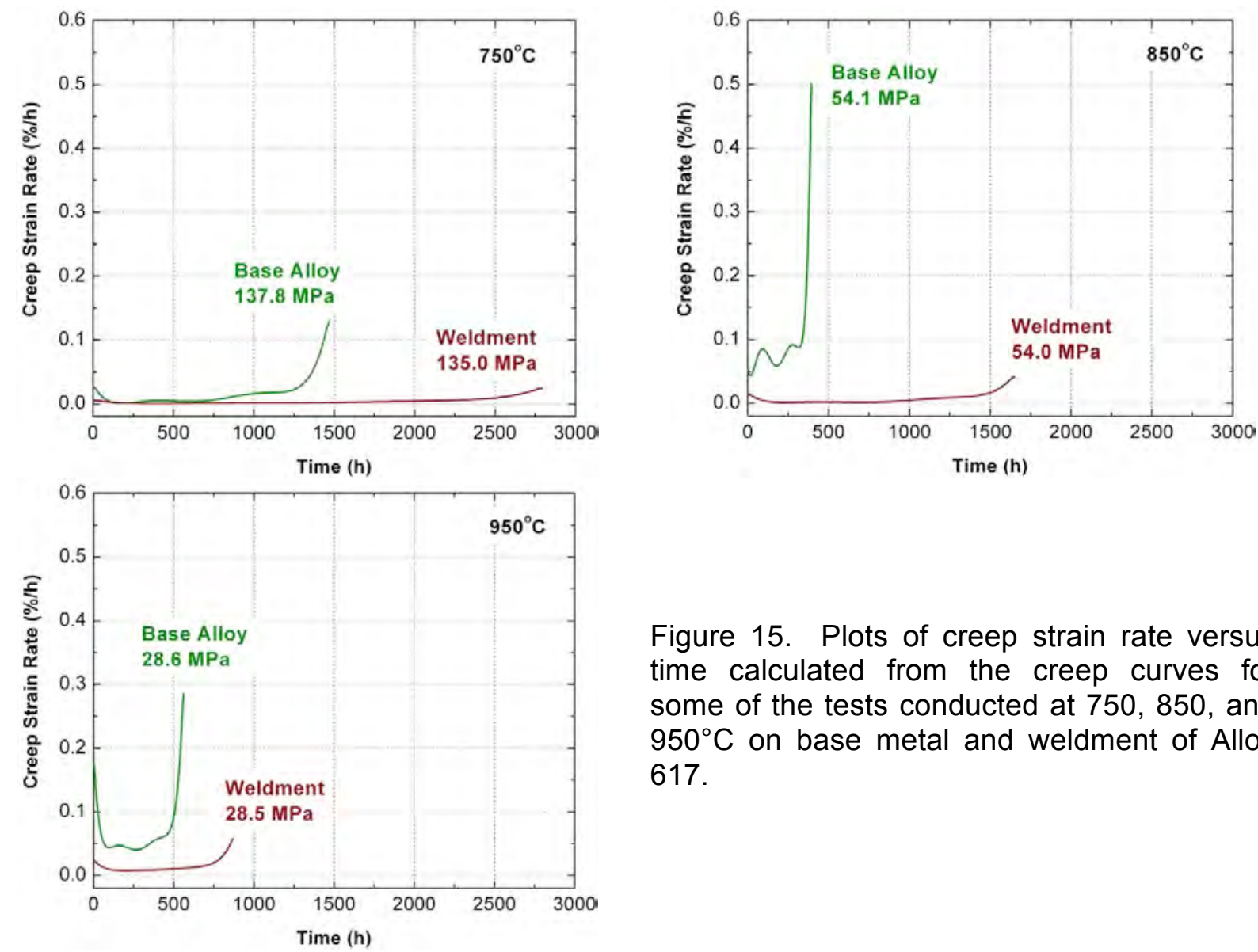

Figure 15. Plots of creep strain rate versus time calculated from the creep curves for some of the tests conducted at 750,850 , and $950^{\circ} \mathrm{C}$ on base metal and weldment of Alloy 617.

\subsection{Creep Correlations}

To quantify the creep behavior more fully, correlations between rupture life and other quantities determined from creep curves with the applied stress and temperature. Defining relationships between rupture life, minimum or secondary or linear creep rate, or time for onset of tertiary creep is useful if it describes the creep behavior of the alloy over a wide range of applied stresses. Furthermore, such relationships, if understood and developed, can be used to evaluate the necessary creep quantities from stress rupture rather than creep rupture tests.

The elevated temperature design rules for fabrication and service of metallic components requires not only a knowledge of rupture behavior but also information on the time to reach a specified strain and the time to onset of tertiary creep. Tertiary creep is generally indicative of material cracking and void formation and therefore, is metallurgically related to material damage. Also, tertiary creep results in material instability, since an increase in strain rate occurs with an increase in strain and strain concentrations induced by creep are accelerated. As a result, a correlation between the rupture life and the time-to-tertiary creep will be useful in determining the onset of instability in design studies. At present, the data developed (shown in 
Table 3) is not sufficient to develop valid creep correlations and ongoing and planned test data will be used to in the future to develop such correlations.

Since the creep behavior of Alloy 617 is somewhat different from the ferritic steels and austenitic stainless steels in that the alloy seems to exhibit accelerating creep for a large portion of the creep life, the creep data developed thus far are analyzed to evaluate the onset of tertiary in Alloy 617. Table 4 lists the creep data developed on the base alloy and on weldments of Alloy 617 at $750-950^{\circ} \mathrm{C}$. The creep curve of each test was analyzed to evaluate the linear creep rate (shown in column 6 in Table 4) and the time span (column 7) in which the creep rate is constant. The last column in the table shows the ratio of the time for onset of tertiary to rupture time. The results indicate that the tertiary creep begins at $\approx 50 \%$ of the rupture time.

Table 4. Additional creep information for Alloy 617 base metal and weldments tested in dry air

\begin{tabular}{|cccccc|c|c|}
\hline $\begin{array}{c}\text { Specimen } \\
\text { ID }\end{array}$ & $\begin{array}{c}\text { Alloy 617 } \\
\text { specimen } \\
\text { Type }\end{array}$ & $\begin{array}{c}\text { Test } \\
\text { temperature } \\
\left({ }^{\circ} \mathrm{C}\right)\end{array}$ & $\begin{array}{c}\text { Applied } \\
\text { stress } \\
(\mathrm{MPa})\end{array}$ & $\begin{array}{c}\text { Rupture } \\
\text { time } \\
(\mathrm{h})\end{array}$ & $\begin{array}{c}\text { Creep rate } \\
(\% / \mathrm{h})\end{array}$ & $\begin{array}{c}\text { Creep rate } \\
\text { time range } \\
(\mathrm{h})\end{array}$ & $\begin{array}{c}\text { Ratio of onset } \\
\text { of tertiary to } \\
\text { rupture time }\end{array}$ \\
\hline H3 & Base Metal & 750 & 137.8 & 1470.0 & $3.20 \times 10^{-03}$ & $100-550$ & 0.37 \\
H1 & Base Metal & 850 & 63.1 & 275.1 & $9.49 \times 10^{-02}$ & $20-140$ & 0.51 \\
H8 & Base Metal & 850 & 63.0 & 260.9 & $1.13 \times 10^{-01}$ & $10-125$ & 0.48 \\
H4 & Base Metal & 850 & 54.1 & 394.4 & $7.11 \times 10^{-02}$ & $30-275$ & 0.70 \\
H7 & Base Metal & 850 & 43.1 & 1115.3 & $2.15 \times 10^{-02}$ & $50-550$ & 0.49 \\
H2 & Base Metal & 950 & 28.6 & 561.8 & $4.41 \times 10^{-02}$ & $100-400$ & 0.71 \\
H5 & Base Metal & 950 & 24.1 & 956.6 & $2.75 \times 10^{-02}$ & $50-500$ & 0.52 \\
$617-1$ & Base Metal & 950 & 18.5 & $3898.7^{* *}$ & $4.23 \times 10^{-03}$ & $100-2000$ & \\
\hline $210-06$ & Weldment & 750 & 135.0 & 2794.9 & $8.32 \times 10^{-04}$ & $200-1500$ & 0.54 \\
$210-09$ & Weldment & 750 & 118.0 & 5953.4 & $4.35 \times 10^{-04}$ & $250-2500$ & 0.42 \\
$210-10$ & Weldment & 750 & 95.0 & $3825.0^{*}$ & $8.40 \times 10^{-05}$ & $300-3000$ & \\
$210-02$ & Weldment & 850 & 61.3 & 1332.4 & $2.85 \times 10^{-03}$ & $50-550$ & 0.41 \\
$617-$ W1 & Weldment & 850 & 62.9 & 936.4 & $2.07 \times 10^{-03}$ & $50-500$ & 0.53 \\
$210-03$ & Weldment & 850 & 54.0 & 1648.6 & $1.73 \times 10^{-03}$ & $100-900$ & 0.55 \\
$617-$ W2 & Weldment & 850 & 54.0 & $2050.0^{*}$ & $1.29 \times 10^{-03}$ & $100-1000$ & \\
$210-07$ & Weldment & 850 & 43.0 & 3226.3 & $6.00 \times 10^{-04}$ & $500-1500$ & 0.46 \\
$210-04$ & Weldment & 950 & 28.5 & 871.1 & $8.18 \times 10^{-03}$ & $50-500$ & 0.57 \\
$210-05$ & Weldment & 950 & 24.1 & 2093.8 & $8.98 \times 10^{-03}$ & $300-1000$ & 0.48 \\
$210-08$ & Weldment & 950 & 18.5 & 4484.5 & $3.00 \times 10^{-03}$ & $300-2500$ & 0.56 \\
\hline
\end{tabular}


Figures 16-19 show the plots of rupture time, minimum creep rate, rupture strain, and reduction in area as a function of applied stress, for tests conducted on the base metal and on the weldments at $750-950^{\circ} \mathrm{C}$.

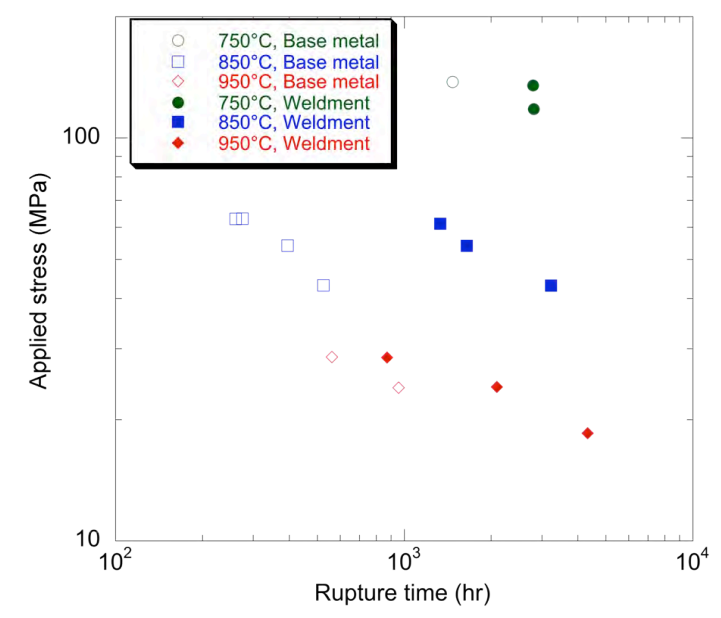

Figure 16. Plot of applied stress versus rupture time for base metal and weldment of Alloy 617 tested at $750-950^{\circ} \mathrm{C}$.

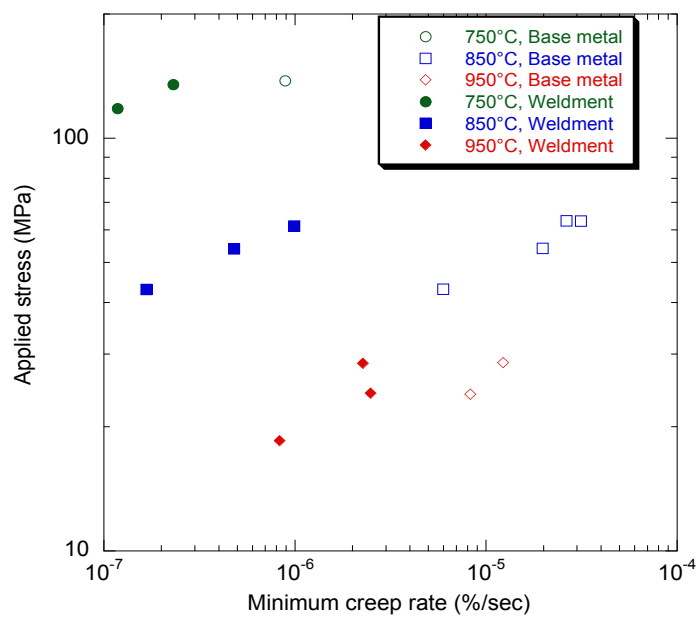

Figure 17. Plot of applied stress versus steady state creep rate for base metal and weldment of Alloy 617 tested at $750-950^{\circ} \mathrm{C}$.

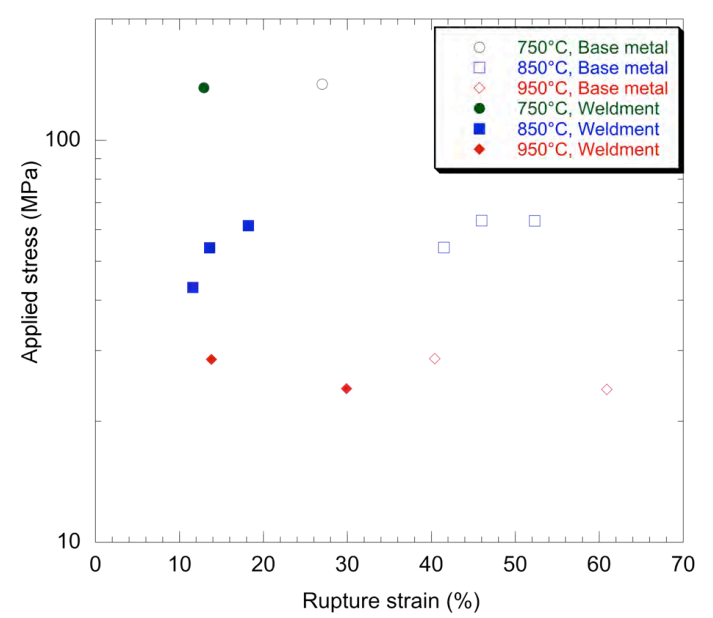

Figure 18. Plot of applied stress versus rupture strain for base metal and weldment of Alloy 617 tested at $750-950^{\circ} \mathrm{C}$. 


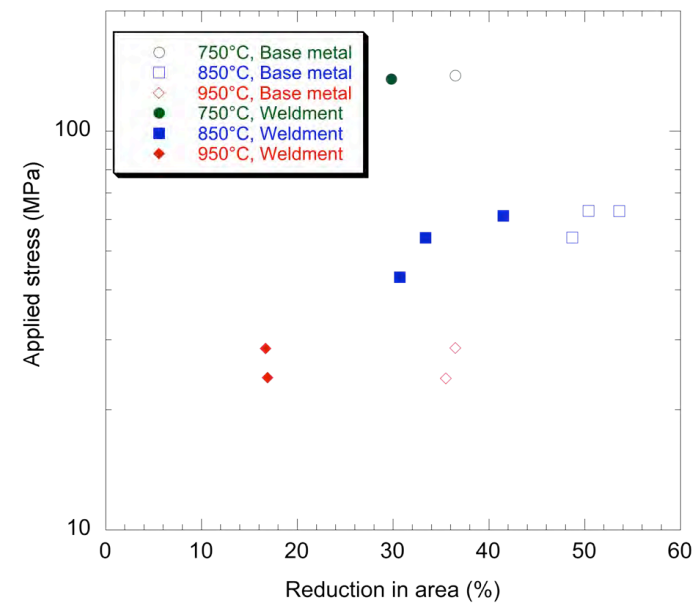

Figure 19. Plot of applied stress versus reduction in area for base metal and weldment of Alloy 617 tested at $750-950^{\circ} \mathrm{C}$.

Figure 20 shows a plot of steady state creep rate as a function of applied stress for the base alloy and weldments of Alloy 617 tested at $750-950^{\circ} \mathrm{C}$. The steady state creep rate is usually expressed as (Sherby and Burke 1967, Natesan et al. 2002)

$$
\dot{\varepsilon}=A \cdot \sigma^{n} \cdot \exp \left(\frac{-Q}{R T}\right)
$$

where $\sigma$ is the applied stress, $\mathrm{n}$ is the stress exponent, $\mathrm{Q}$ is the activation energy for creep mechanism, $A$ is a constant, $R$ is the universal gas constant, and $T$ is the absolute temperature. The value of $n$ and $Q$ can be estimated by a multiple regression analysis of the creep data at different temperatures and stresses and will be computed with additional test data being generated. However, qualitatively it can be seen from Fig. 20, a similar slope for the lines drawn through the data sets obtained at different temperatures for both the base metal and weldment specimens. This indicates that the stress exponent for creep is the same and one can infer that the same mechanism is operative in both base metal and weldments in the temperature range of the current study.

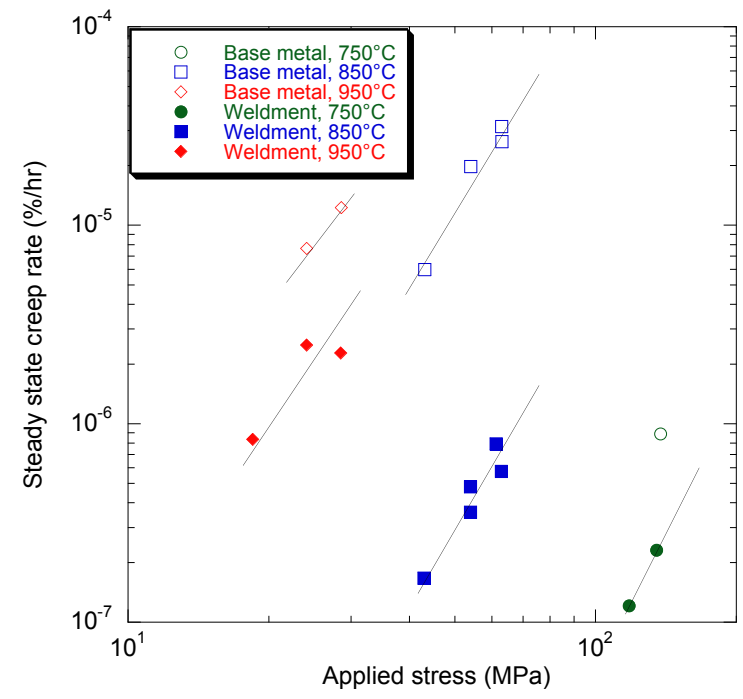

Figure 20. Plot of steady state creep rate versus applied stress for base metal and weldment of Alloy 617 tested at $750-950^{\circ} \mathrm{C}$. 
An attempt was made to correlate the creep data using the Larson-Miller parameter, which incorporates the temperature and time in a single parameter. Figure 21 shows a plot of applied stress versus Larson-Miller parameter for the tests conducted on the base metal and weldments at $750-950^{\circ} \mathrm{C}$. The weldment data at all three temperatures can be fitted by a single line, but the data of the base metal exhibit significant departure from the line, especially at $950^{\circ} \mathrm{C}$. Data from ongoing tests may aid in developing a better correlation.

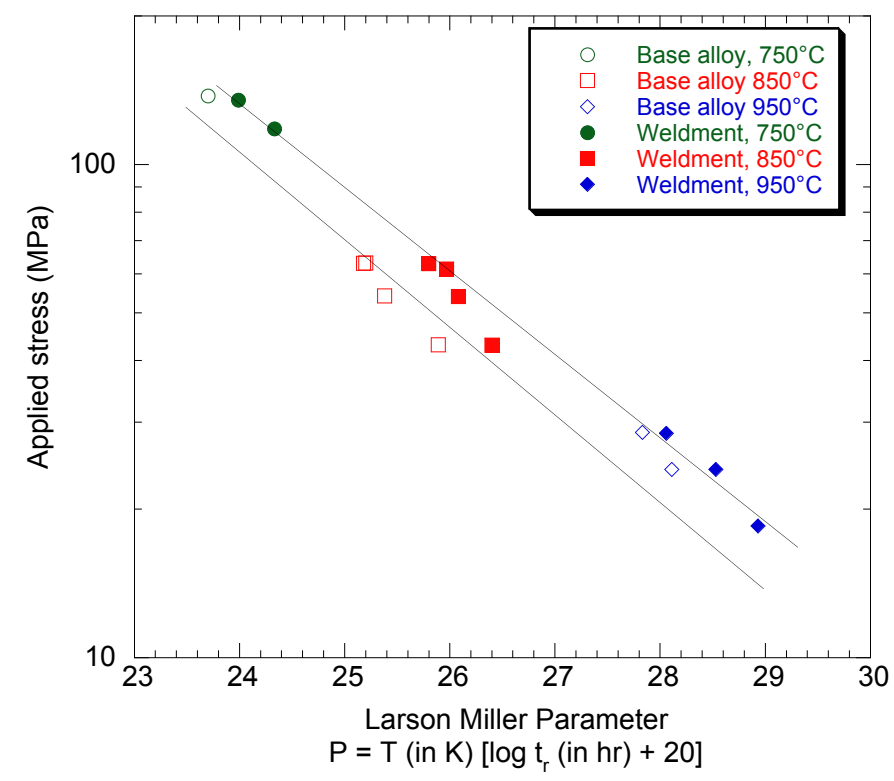

Figure 21. Plot of applied stress versus Larson Miller parameter for base metal and weldment of Alloy 617 tested at $750-950^{\circ} \mathrm{C}$.

\subsection{Microstructural Observations}

\section{Fractography}

After creep failure, the fracture surface of each tested specimen was examined by scanning electron microscopy (SEM) and documented with SEM micrographs.

Figure 22 shows SEM micrographs taken at two magnifications showing fracture modes in specimen $\mathrm{H} 3$ of Alloy 617 base metal tested at the stress level of $137.8 \mathrm{MPa}$ at $750^{\circ} \mathrm{C}$ in air. The fracture surface shows predominantly dimple rupture and extensive secondary cracking with indication of intergranular cracking. Surface oxidation is evident due to prolonged exposure to air.

Figure 23 shows SEM micrographs taken at two magnifications showing fracture modes in specimen $\mathrm{H} 1$ of Alloy 617 base metal tested at the stress level of $63.1 \mathrm{MPa}$ at $850^{\circ} \mathrm{C}$ in air. The fracture surface shows showed a combination of dimpled rupture and intergranular cracking.

Figure 24 shows SEM micrographs taken at two magnifications showing fracture modes in specimen $\mathrm{H} 4$ of Alloy 617 base metal tested at the stress level of $54.1 \mathrm{MPa}$ at $850^{\circ} \mathrm{C}$ in air. Dimpled rupture and intergranular cracking was observed, similar to the fracture modes observed in specimen $\mathrm{H} 1$. 


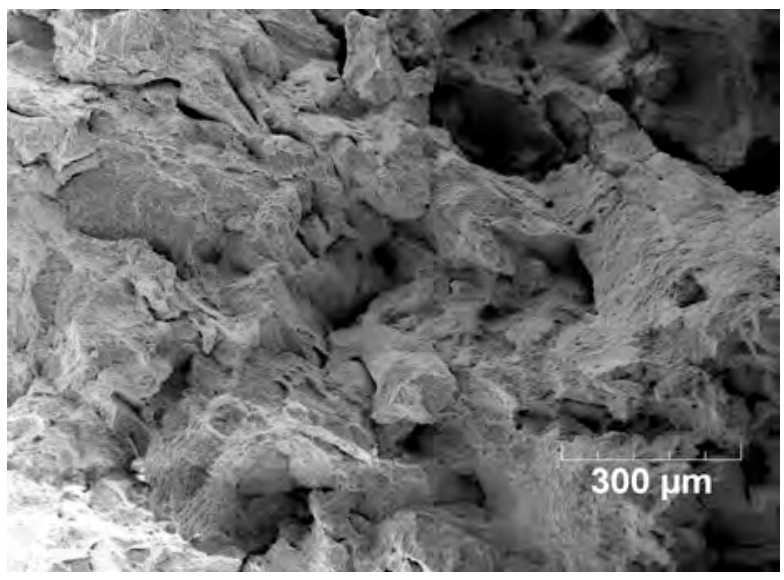

(a)

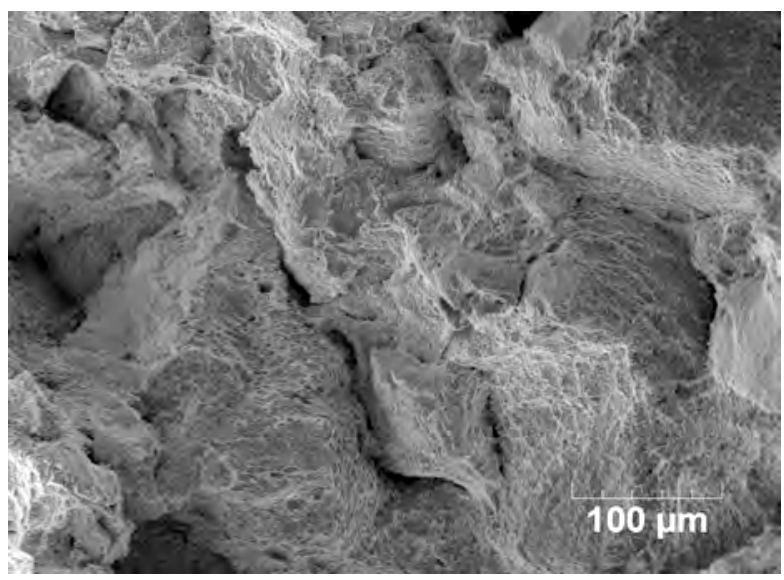

(b)

Figure 22. SEM micrographs of the fracture surfaces for Alloy 617 base metal tested at the stress level of $137.8 \mathrm{MPa}$ at $750^{\circ} \mathrm{C}$ in air (ID: H3).

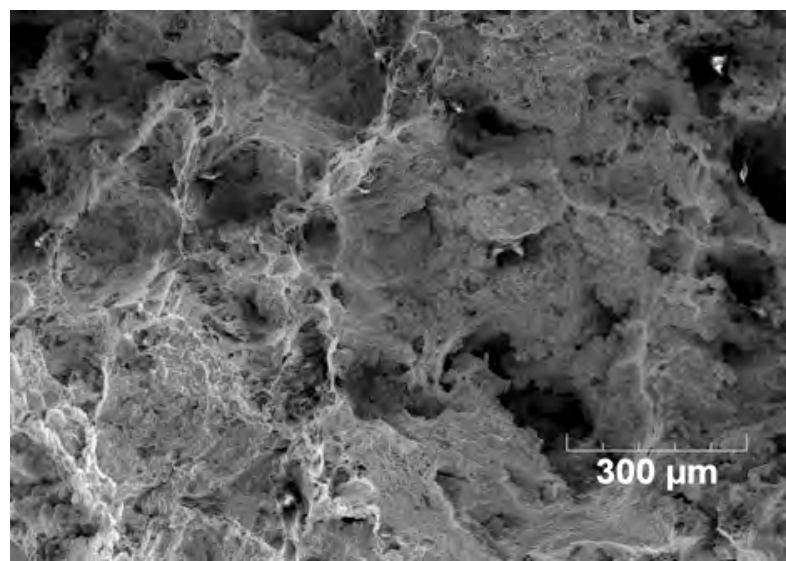

(a)

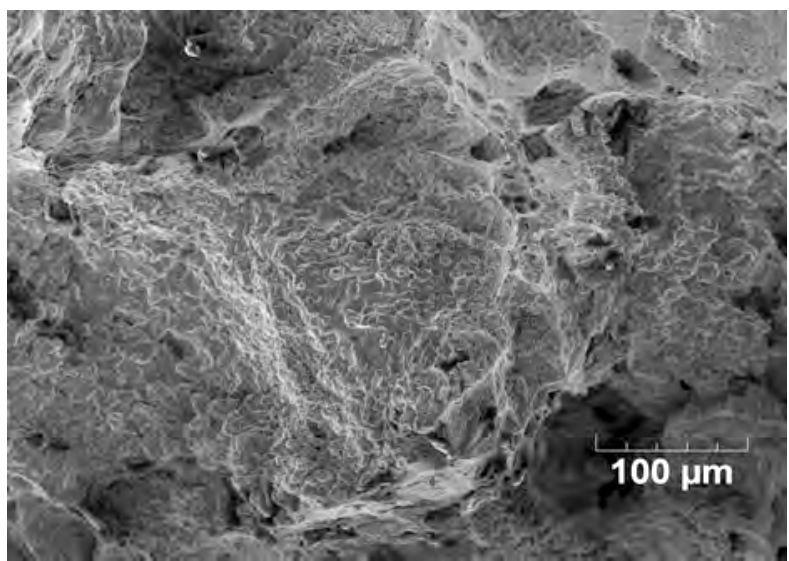

(b)

Figure 23. SEM micrographs of the fracture surfaces for Alloy 617 base metal tested at the stress level of $63.1 \mathrm{MPa}$ at $850^{\circ} \mathrm{C}$ in air (ID: H1).

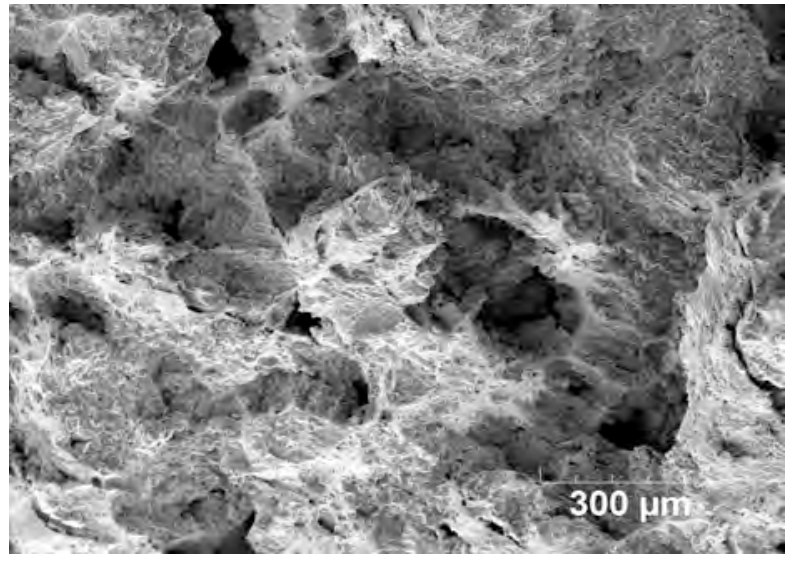

(a)

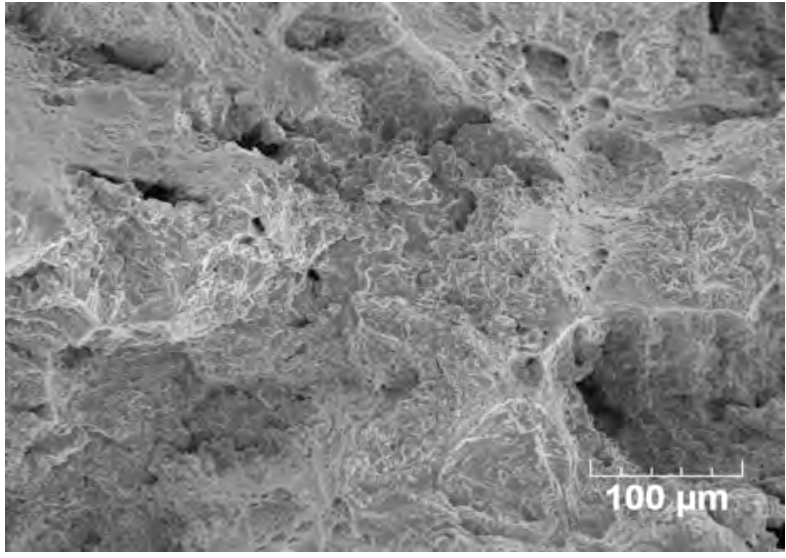

(b)

Figure 24. SEM micrographs of the fracture surfaces for Alloy 617 base metal tested at the stress level of $54.1 \mathrm{MPa}$ at $850^{\circ} \mathrm{C}$ in air (ID: H4). 
Figure 25 shows SEM micrographs taken at two magnifications showing fracture modes in specimen 210-02 of Alloy 617 weldment tested at the stress level of $63.1 \mathrm{MPa}$ at $850^{\circ} \mathrm{C}$ in air. The fracture surface showed dimpled rupture and intergranular cracking. Compared with the fracture surface of the base alloy specimen tested at similar stress levels and temperature, intergranular cracking was more pronounced in the weldment.

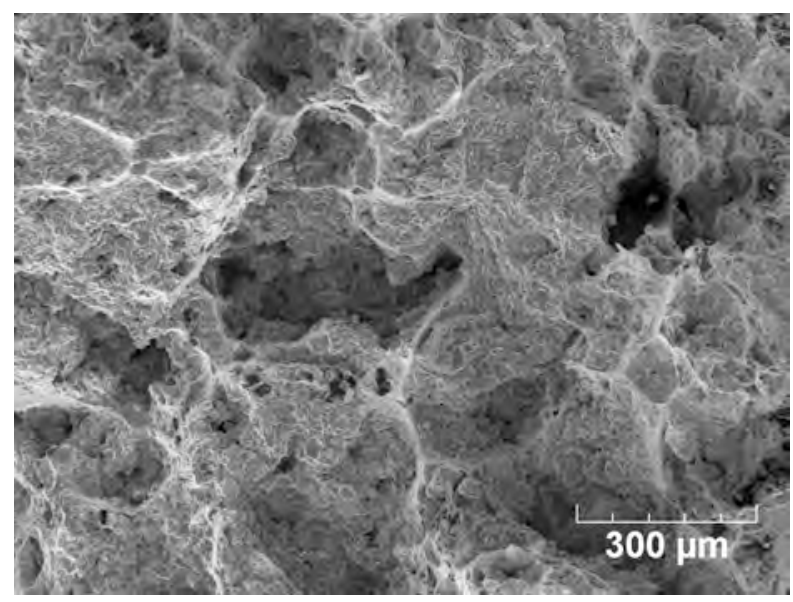

(a)

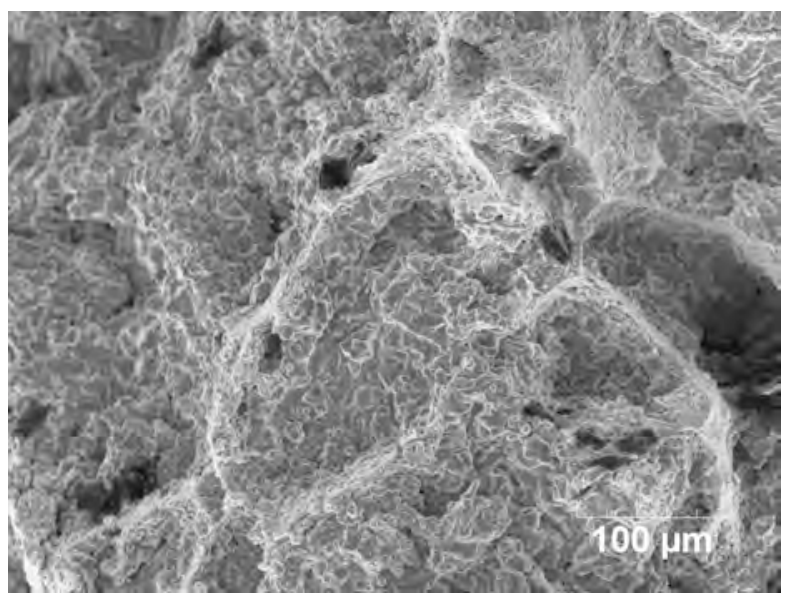

(b)

Figure 25. SEM micrographs of the fracture surfaces for Alloy 617 weldment tested at a stress level of $63.1 \mathrm{MPa}$ at $850^{\circ} \mathrm{C}$ in air (ID: 210-02).

Figure 26 shows SEM micrographs taken at two magnifications showing fracture modes in specimen 210-03 of Alloy 617 weldment tested at the stress level of $54.1 \mathrm{MPa}$ at $850^{\circ} \mathrm{C}$ in air. Similar to the fracture modes observed on the fracture surface of specimen 210-02, the fracture surface showed dimple rupture along with evident grain boundary cracking.

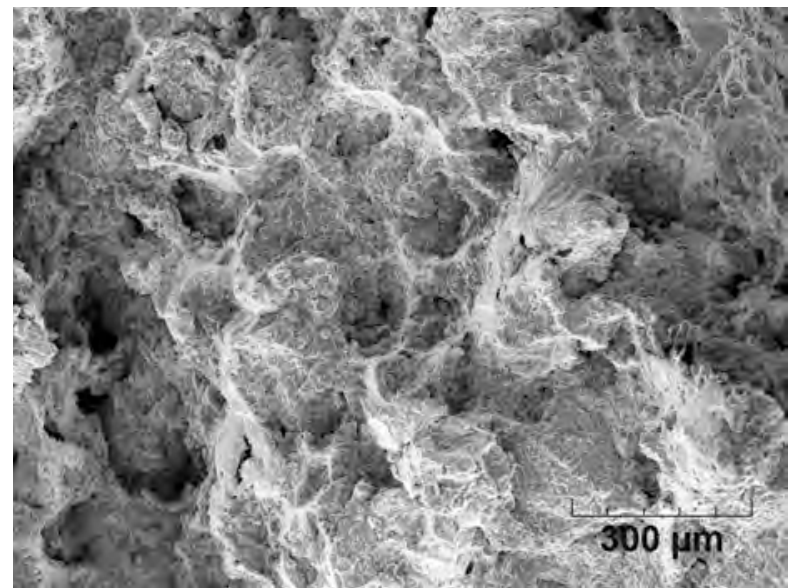

(a)

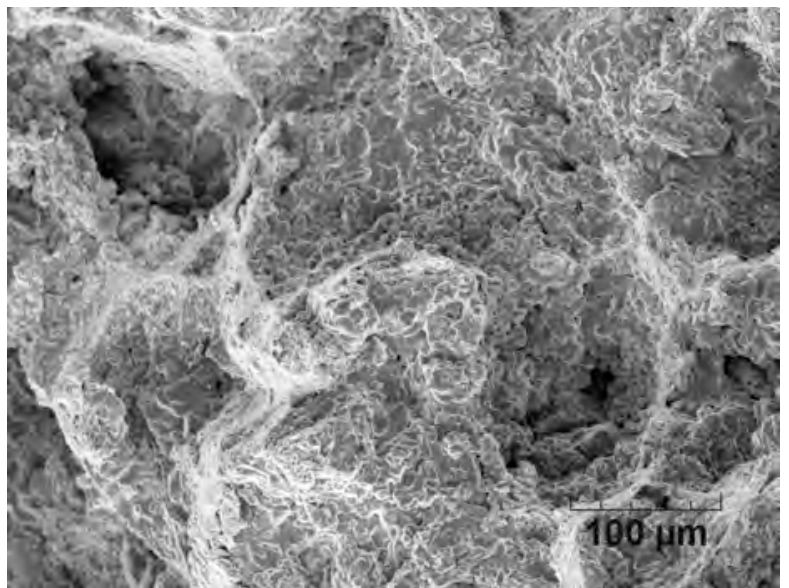

(b)

Figure 26. SEM micrographs of the fracture surfaces for Alloy 617 weldment tested at a stress level of $54.1 \mathrm{MPa}$ at $850^{\circ} \mathrm{C}$ in air (ID: 210-03).

Figures 27 and 28 shows SEM micrographs taken at two magnifications showing fracture modes in specimen $\mathrm{H} 2$ of Alloy 617 base metal tested at the stress level of $28.6 \mathrm{MPa}$ and specimen 210-04 of Alloy 617 weldment tested at the stress level of $28.5 \mathrm{MPa}$ at $950^{\circ} \mathrm{C}$ in air, respectively. While both specimens showed dominant dimple rupture along with intergranular cracking, intergranular cracking is more evident in the weldement specimen. 


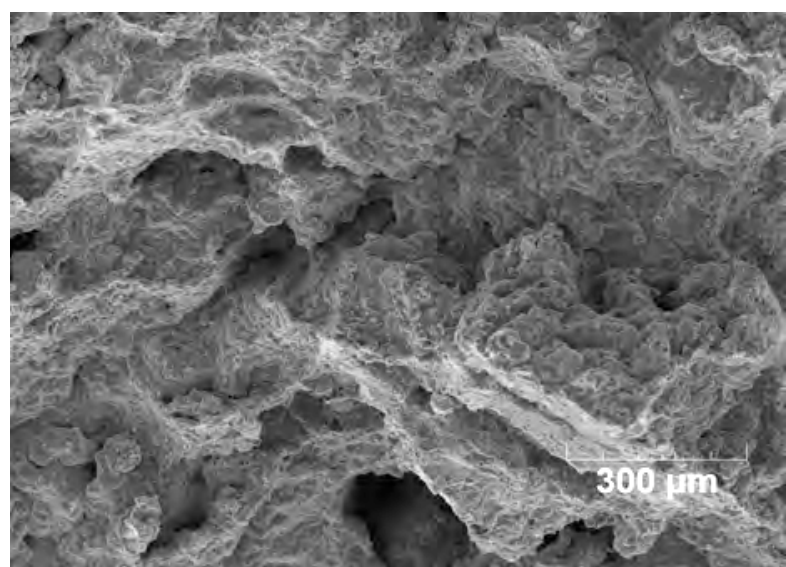

(a)

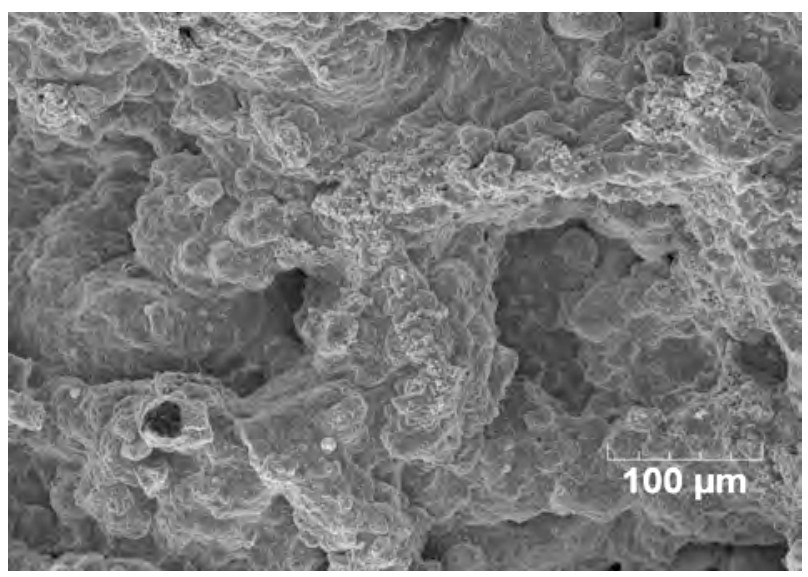

(b)

Figure 27. SEM micrographs of the fracture surfaces for Alloy 617 base metal tested at the stress level of $28.6 \mathrm{MPa}$ at $950^{\circ} \mathrm{C}$ in air (ID: H2).

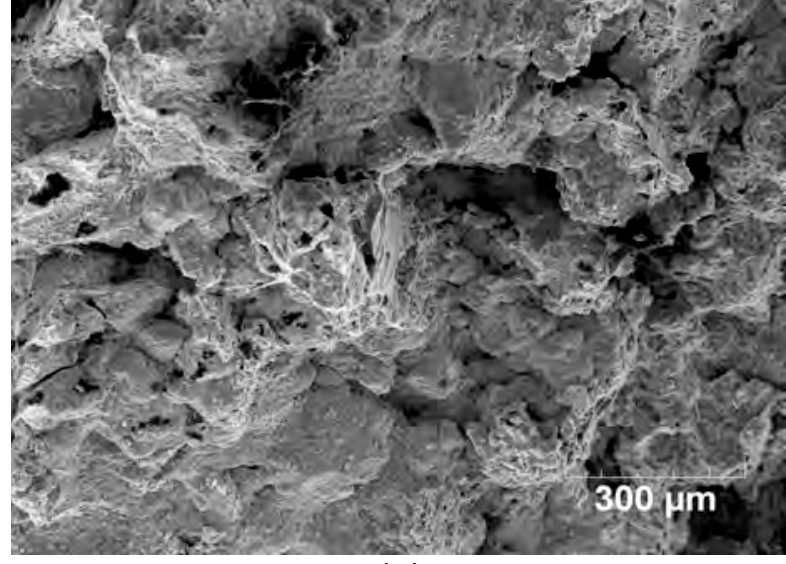

(a)

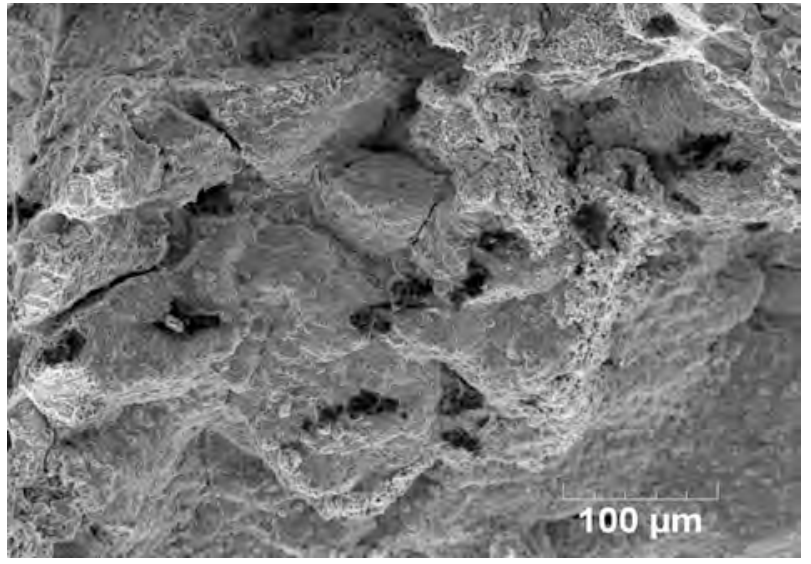

(b)

Figure 28. SEM micrographs of the fracture surfaces for Alloy 617 weldment tested at the stress level of $28.5 \mathrm{MPa}$ at $950^{\circ} \mathrm{C}$ in air (ID: 210-04).

Figures 29 and 30 show a comparison of the fracture morphologies of base metal and weldment of Alloy 617 after creep testing at 750 and $950^{\circ} \mathrm{C}$, respectively. SEM fractography analysis indicates that both base metal and weldment showed combined fracture modes consisting of dimple rupture and intergranular cracking. Intergranular cracking is more evident in the weldment specimens, which is consistent with the observation of lower creep ductility in the weldment than in the base metal. The fracture in most of the weldment specimens occurred in the vicinity of the heat-affected zone, except for the specimen 210-08 in which the fracture was in the weld zone. The rupture strain and reduction in area values of $7.1 \%$ and $3.3 \%$, respectively, for this specimen are indicative of the weld metal properties at $950^{\circ} \mathrm{C}$.

Figure 31 shows optical micrographs of polished and etched longitudinal sections of various Alloy 617 base metal specimens creep tested at 750,850 , and $950^{\circ} \mathrm{C}$. Under all these three creep conditions, the alloy showed significant intergranular cracking near the specimen surface and in the bulk.

Figure 32 shows optical micrographs of polished and etched longitudinal sections of two Alloy 617 weldment specimens creep tested at 750 and $950^{\circ} \mathrm{C}$. Significant intergranular cracking in the heat affected zone was observed in the weldment creep specimen tested at $750^{\circ} \mathrm{C}, 135.0$ 
$\mathrm{MPa}$, while cracking occurred in the weld zone and the heat affected zone was free of cracking in the specimen tested at $950^{\circ} \mathrm{C}, 18.5 \mathrm{MPa}$, consistent with the SEM fractography results.

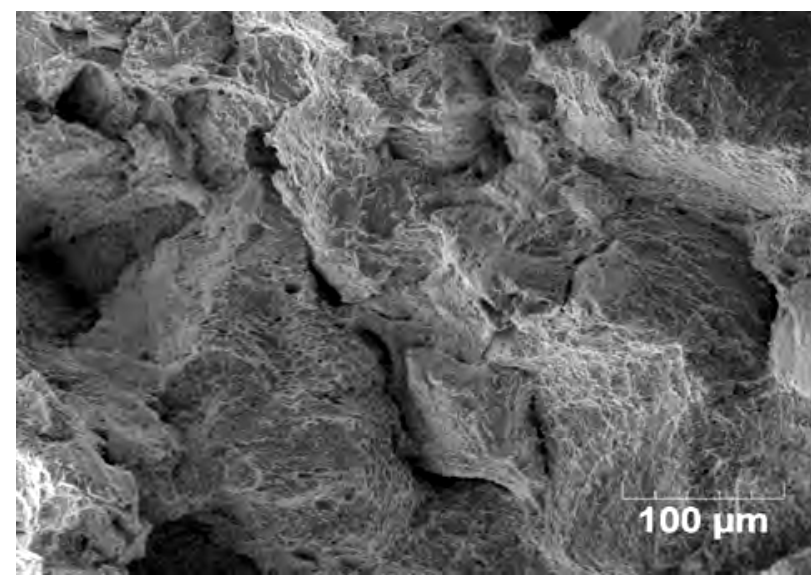

(a)

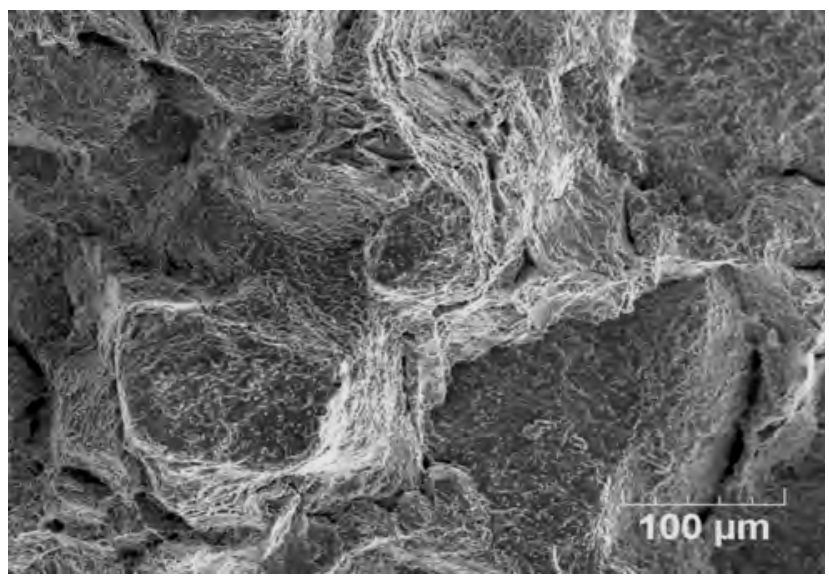

(b)

Figure 29. SEM micrographs of the fracture surfaces for Alloy 617 (a) base alloy and (b) weldment tested in air at the stress levels of 137.8 and $135 \mathrm{MPa}$, respectively, at $750^{\circ} \mathrm{C}$.

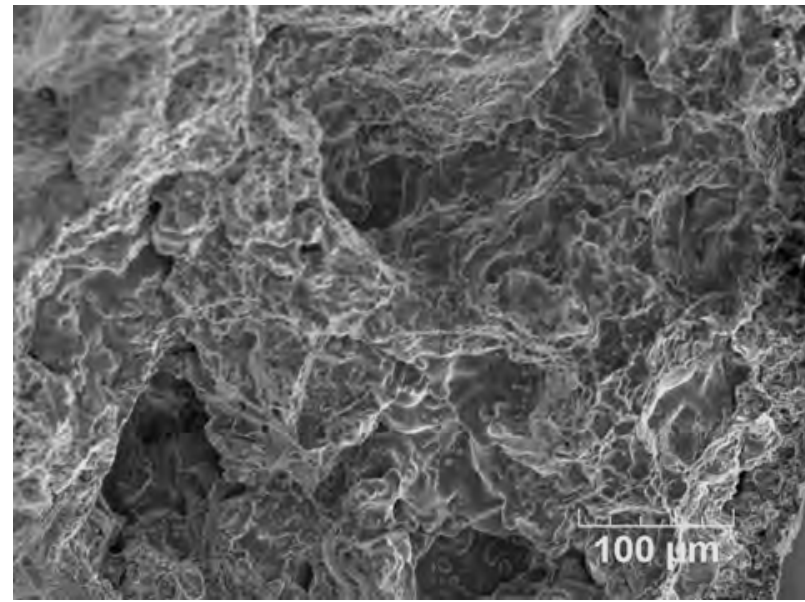

(a)

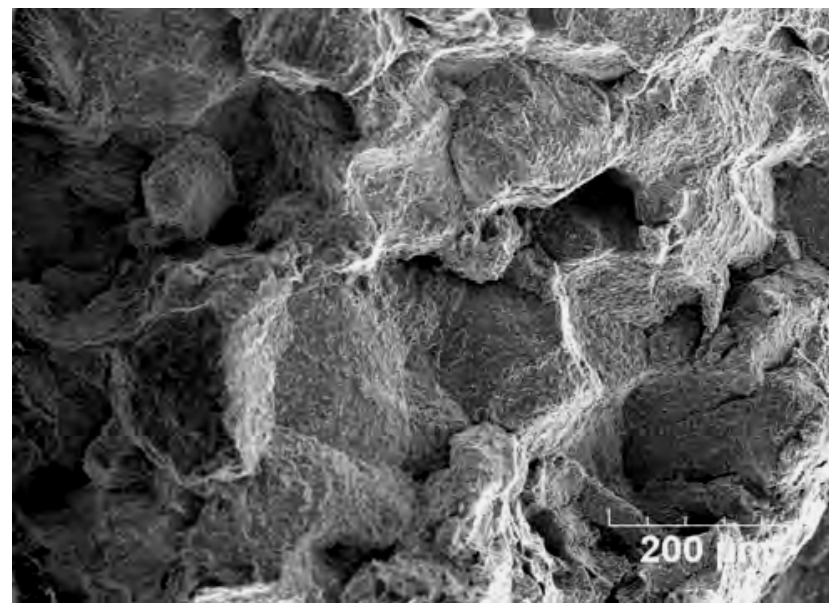

(b)

Figure 30. SEM micrographs of the fracture surfaces for Alloy 617 (a) base alloy and (b) weldment tested in air at the stress level of $24.1 \mathrm{MPa}$ at $950^{\circ} \mathrm{C}$.

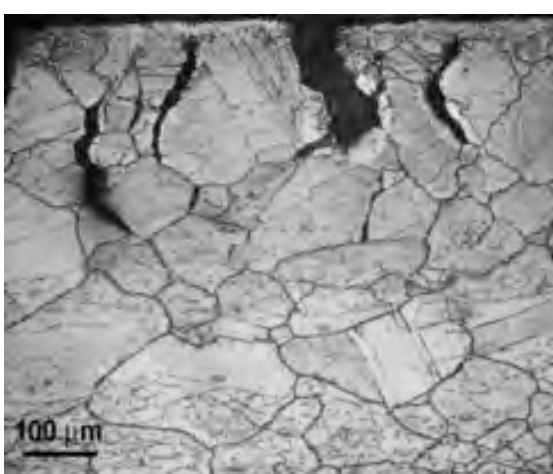

(a)

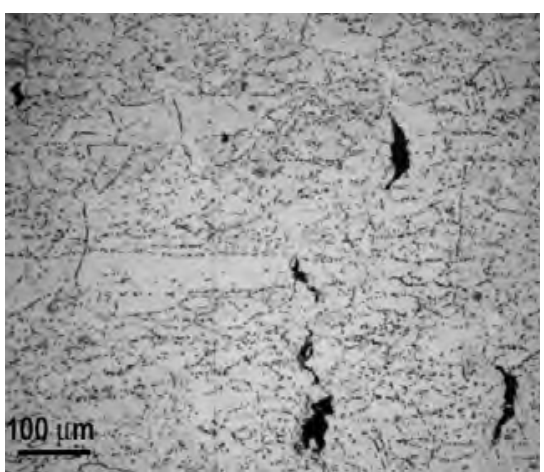

(b)

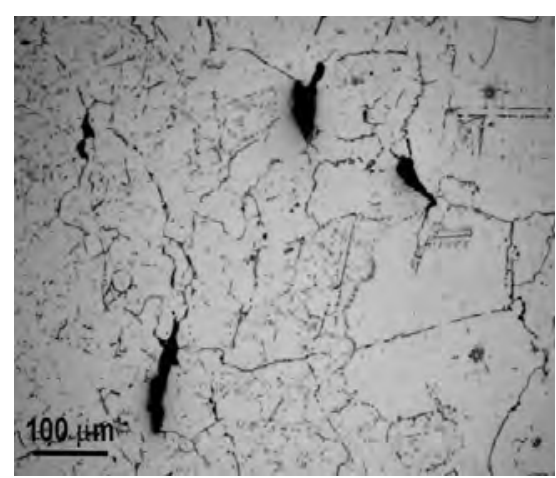

(c) 
Figure 31. Optical micrographs of the longitudinal sections of Alloy 617 base metal specimens tested at (a) $750^{\circ} \mathrm{C}, 137.8 \mathrm{MPa}$, (b) $850^{\circ} \mathrm{C}, 54.1 \mathrm{MPa}$, and (c) $950^{\circ} \mathrm{C}, 28.6 \mathrm{MPa}$.
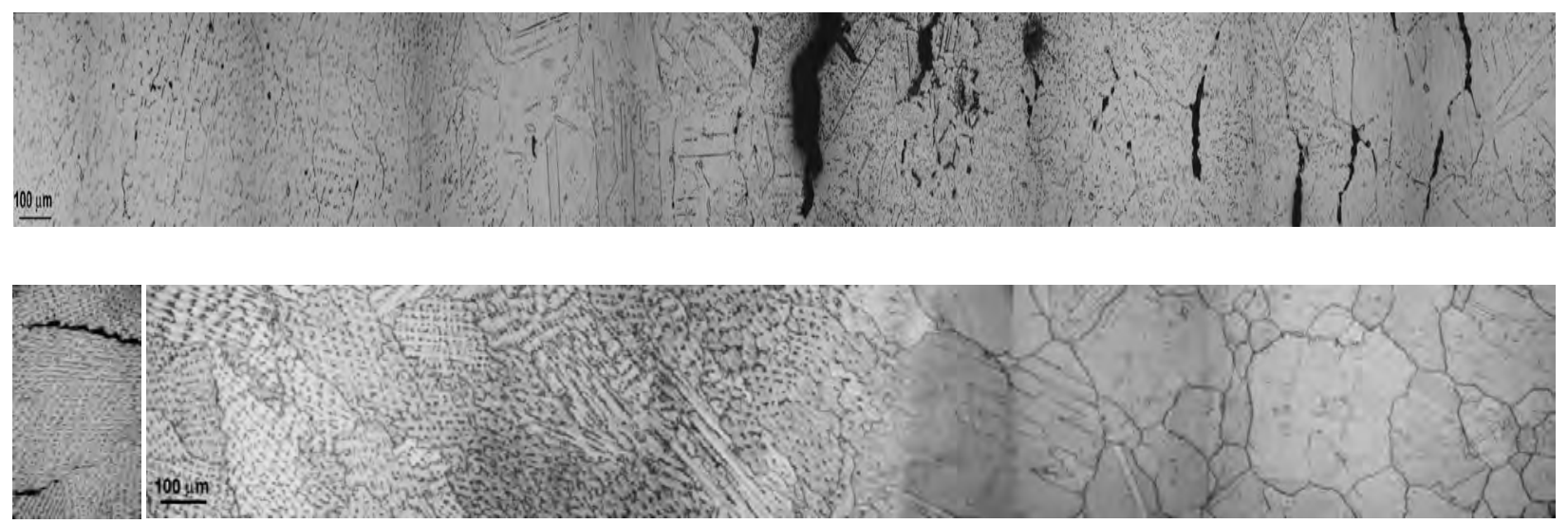

Figure 32. Optical micrographs of the longitudinal sections of Alloy 617 weldment specimens tested at (top) $950^{\circ} \mathrm{C}, 18.5 \mathrm{MPa}$ and (bottom) $750^{\circ} \mathrm{C}, 135.0 \mathrm{MPa}$.

SEM fractography analysis and cracking behavior examined by optical microscopy indicates that both base metal and weldment showed combined fracture modes consisting of dimple rupture and intergranular cracking. A majority of weldment specimens failed in the heat-affected zone with extensive intergranular cracking, with one exception that cracking occurred in the weld zone. Intergranular cracking is more evident in the weldment specimens, which is consistent with the observation of lower creep ductility in the weldment than in the base metal.

Additional creep tests are in progress to develop a mechanistic understanding of creep deformation in base alloy and weldments and also to develop a database on creep performance of weldments. It is planned to quantify the test data to develop correlations of creep properties with exposure time and temperature. Detailed microstructural analysis on polished sections (in addition to fractography) of tested specimens is planned to develop a mechanistic understanding of the weld behavior, especially with regard to the decrease in ductility.

\section{Summary}

A test program is being conducted at Argonne National Laboratory to evaluate the creep properties of Alloy 617 base metal and weldments. The emphasis in the program is develop a mechanistic understanding of the creep deformation in Alloy 617 base metal and gas-tungstenarc applied weldments and to quantify the creep properties of the welded material and compare its performance with that of the base metal over a temperature range of $750-1000^{\circ} \mathrm{C}$ and over a wide range of applied stress levels. Several creep-test facilities have been set up to conduct the program under quality assurance NQA-1level.

Creep test specimens were designed and fabricated, by Idaho National Laboratory, using the Alloy 617 base metal and gas-tungsten-arc welded plate of Alloy 617. During the past year, several creep tests were conducted in air on Alloy 617 base metal and weldment specimens at temperatures of 750,850 , and $950^{\circ} \mathrm{C}$. Among these tests eight tests were conducted on Alloy 617 base metal specimens and nine were on Alloy 617 weldments. The creep rupture times for the base alloy and weldment tests were up to $\sim 3900$ and $\sim 4500 \mathrm{~h}$, respectively. The results 
showed that the creep rupture lives of weld specimens are much longer than those for the base alloy, when tested under identical conditions. The test results also showed that the creep strain at fracture is in the range of $7-18 \%$ for weldment samples and were much lower than those for the base alloy, under similar test conditions.

In general, the weldment specimens showed more of a flat or constant creep rate region than the base metal specimens. The base alloy and the weldment exhibited tertiary creep after 50$60 \%$ of the rupture life, irrespective of test temperature in the range of $750-950^{\circ} \mathrm{C}$. The results showed that the stress dependence of the creep rate followed a power law for both base alloy and weldments. The data also showed that the stress exponent for creep is the same and one can infer that the same mechanism is operative in both base metal and weldments in the temperature range of the current study.

The creep test data and the fractography information presented in this report indicate a longer creep life for the welded specimens when compared to the data for the base alloy. However, the rupture ductility values for the welded specimens are substantially less than those for the base alloy, under identical test conditions. SEM fractography analysis indicated that both base metal and weldment showed combined fracture modes consisting of dimple rupture and intergranular cracking. Intergranular cracking was more evident in the weldment specimens, which is consistent with the observation of lower creep ductility in the weldment than in the base metal. 


\section{References}

Cook, R. H., 1984, "Creep Properties of Inconel-617 in Air and Helium at 800 to $1000^{\circ} \mathrm{C}$," Nuclear Technology, 66, 283.

Generation IV International Forum, 2002, A Technology Roadmap for Generation IV Nuclear Energy Systems, U.S. DOE Nuclear Energy Advisory Committee and the Generation IV International Forum, FIF-002-00.

Natesan, K., A. Purohit, and S. W. Tam, 2003, "Materials Behabior in HTGR Environments," NUREG/CR-6824/ANL-02/37.

Natesan, K., A. Moisseytsev, S. Majumdar, and P. S. Shankar, 2006, "Preliminary Issues Associated with the Next Generation Nuclear Plant Intermediate Heat Exchanger Design," Argonne National Laboratory Report, ANL/EXT-06/46.

Natesan, K., W. K. Soppet, and A. Purohit, 2002, J. Nuc. Mat., 307-311, 585-590.

Osthoff, W., H. Schuster, and P. Ennis, 1984, "Creep and Relaxation Behavior of Inconel-617," Nuclear Technology, 66, 296.

Schneider, K., W. Hartnagel, P. Schepp, and B. Ilschner, 1984, "Creep Behavior of Materials for High-Temperature Reactor Application," Nuclear Technology, 66, 289

Schubert, F., U. Bruch, R. Cook, H. Diehl, P. J. Ennis, W. Jakobeit, H. J. Penkalla, E. T. Heesen, and G. Ullrich, 1984, "Creep Rupture Behavior of Candidate Materials for Nuclear Process Heat Applications," Nuclear Technology, 66, 227.

Sherby, O. D. and P. M. Burke, 1967, Prog. Mater. Sci., 13, 325-390.

Tanabe, T., Y. Sakai, T. Shikama, M. Fujitsuka, H. Yoshida, and R. Watanabe, 1984, "Creep Rupture Properties of Superalloys Developed for Nuclear Steelmaking," Nuclear Technology, 66, 260. 


\section{Argonne}

Nuclear Engineering Division

Argonne National Laboratory

9700 South Case Avenue

Argonne, IL 60439

www.anl.gov 